\title{
Construction of polycistronic baculovirus surface display vectors to express the PCV2 Cap(d41) protein and analysis of its immunogenicity in mice and swine
}

Ya-Yi Chen ${ }^{1,2+}$, Wei-Chen Yang ${ }^{3 \dagger}$, Yu-Kang Chang ${ }^{4,5}$, Chi-Young Wang ${ }^{6}$, Wei-Ru Huang ${ }^{3,10}$, Jyun-Yi Li $i^{3,10}$, Kuo-Pin Chuang ${ }^{7}$, Hung-Yi Wu ${ }^{8}$, Ching-Dong Chang ${ }^{8}$, Brent L. Nielsen ${ }^{9}$ and Hung-Jen Liu $3,10,11,12,13^{*}$ (D)

\begin{abstract}
To increase expression levels of the PCV2 Cap(d41) protein, novel baculovirus surface display vectors with multiple expression cassettes were constructed to create recombinant baculoviruses BacSC-Cap(d41), BacDD-2Cap(d41), BacDD-3Cap(d41), and BacDD-4Cap(d41). Our results reveal that the recombinant baculovirus BacDD-4Cap(d41) was able to express the highest levels of Cap(d41) protein. Optimum conditions for expressing the PCV2 Cap (d41) protein were determined, and our results show that $10^{7}$ of Sf-9 infected with the recombinant baculovirus BacDD-4Cap(d41) at an $\mathrm{MOI}$ of 5 for 3 days showed the highest level of protein expression. Mice immunized with the 4Cap $(\mathrm{d} 41)$ vaccine which was prepared from the recombinant baculovirus-infected cells $\left(10^{7}\right)$ elicited higher ELISA titers compared to the Cap (d41) vaccine. The 4Cap(d41) vaccine could elicit anti-PCV2 neutralizing antibodies and IFN- $\gamma$ in mice, as confirmed by virus neutralization test and IFN- $\gamma$ ELISA. Moreover, the swine lymphocyte proliferative responses indicated that the $4 \mathrm{Cap}(\mathrm{d} 41)$ vaccine was able to induce a clear cellular immune response. Flow cytometry analysis showed that the percentage of $\mathrm{CD}^{+} \mathrm{T}$ cells and $\mathrm{CD} 4^{+} / \mathrm{CD} 8^{+}$ratio was increased significantly in SPF pigs immunized with the 4Cap(d41) vaccine. Importantly, the 4Cap(d41) vaccine induced an IFN- $\gamma$ response, further confirming that its effect is through cellular immunity in SPF pigs. An in vivo challenge study revealed that the 4Cap $(d 41)$ and the commercial vaccine groups significantly reduce the viral load of vaccinated pigs as compared with the CE negative control group. Taken together, we have successfully developed a 4Cap $(d 41)$ vaccine that may be a potential subunit vaccine for preventing the disease associated with PCV2 infections.
\end{abstract}

Keywords: PCV2, Cap protein, baculovirus surface display vectors, 4Cap(d41) vaccine, virus neutralization test, cellular immune response, $C D 4^{+} \mathrm{T}$ cells, IFN- $\gamma$

*Correspondence: hjliu5257@nchu.edu.tw

${ }^{\dagger} Y a-Y i$ Chen and Wei-Chen Yang contributed equally to this work

${ }^{3}$ Institute of Molecular Biology, National Chung Hsing University, Taichung 402, Taiwan

Full list of author information is available at the end of the article

\section{Introduction}

Porcine circoviruses (PCVs) are very small non-enveloped animal viruses with circular single-stranded DNA genomes of approximately $2 \mathrm{~kb}$, which belong to the genus Circovirus in the family Circoviridae [1]. In pigs, four circovirus species (PCV1, PCV2, PCV3, and PCV4) within the genus Circovirus have been identified [1-3]. PCV1 is non-pathogenic and exists in contaminated pig kidney cell lines (porcine kidney

(c) The Author(s) 2020. This article is licensed under a Creative Commons Attribution 4.0 International License, which permits use, sharing, adaptation, distribution and reproduction in any medium or format, as long as you give appropriate credit to the original author(s) and the source, provide a link to the Creative Commons licence, and indicate if changes were made. The images or other third party material in this article are included in the article's Creative Commons licence, unless indicated otherwise in a credit line to the material. If material is not included in the article's Creative Commons licence and your intended use is not permitted by statutory regulation or exceeds the permitted use, you will need to obtain permission directly from the copyright holder. To view a copy of this licence, visit http://creativeco mmons.org/licenses/by/4.0/. The Creative Commons Public Domain Dedication waiver (http://creativecommons.org/publicdomain/ zero/1.0/) applies to the data made available in this article, unless otherwise stated in a credit line to the data. 
15, PK-15) and various pig tissues [1], wherase PCV2 is pathogenic and can cause pigs to develop postweaning multisystemic wasting syndrome (PMWS) [3]. The genome contains two main open reading frames (ORFs), ORF1 and ORF2. The PCV2 capsid protein (Cap) is the major structural viral proteins encoded by ORF2, which contains specific epitopes and induces specific neutralizing antibodies in the host [4-6]. Several reports suggested that this gene has great potential as a recombinant vaccine [5, 7]. Typical PMWS includes progressive weight loss, dyspnea, diarrhea, lower jaw, jaundice, inguinal lymphadenopathy, and systemic lymphocyte depletion $[8,9]$. Severe cases can lead to death, causing economic losses for pig farmers in various countries in the world $[10,11]$. The first case of PMWS was discovered in North America in 1991 $[12,13]$, and similar case reports were subsequently submitted in Spain, the United States, Denmark, Ireland, and other countries [14-17]. A suspected case of PMWS was discovered in Taiwan in 1995, and was first confirmed in 1997 to be PMWS with a mortality rate of about 5-20\% [18]. At present, PCV2 infection in Taiwan is very common, and the mixed infection with other viruses or bacteria is also very serious. Therefore, the development of vaccines for comprehensive epidemic prevention is still the most effective way to deal with this problem.

The aim of this study is to construct novel baculovirus surface display vectors with multiple expression cassettes to enhance the expression levels of the PCV2 Cap protein and to develop a Cap subunit vaccine. We found that the recombinant baculovirus BacDD4Cap(d41) was capable of expressing higher levels of Cap $(\mathrm{d} 41)$ protein than other recombinant baculoviruses. Optimum conditions for expressing the PCV2 $\mathrm{Cap}(\mathrm{d} 41)$ protein were determined, and it was found that 3 days post infection with an MOI 5 or 10 yield the highest levels of protein expression. Mice immunized with the Cap $(\mathrm{d} 41)$ vaccine which was prepared from the $10^{7}$ of $\mathrm{Sf}-9$ cell lysates infected with the BacDD-4Cap(d41) recombinant baculovirus at an MOI of 10 for 3 days had higher ELISA titers than that of cell numbers of $10^{5}$ and $10^{6}$. Furthermore, ELISA and virus neutralization test showed that the $4 \mathrm{Cap}(\mathrm{d} 41)$ vaccine could elicit anti-PCV2 neutralizing antibodies and cellular immune response in mouse and specific pathogen-free (SPF) pigs. An in vivo challenge study showed the 4Cap(d41)-immunized pigs had significantly lower PCV2 viremia than that of the negative control group. The $4 \mathrm{Cap}(\mathrm{d} 41)$ vaccine has promise as a potential subunit vaccine for preventing the disease associated with PCV2 infections.

\section{Materials and methods}

\section{Cells and viruses}

The Spodoptera frugiperda (Sf-9) cell lines were grown as monolayers in TNM-FH medium (Sigma, St. Louis, USA) supplemented with $10 \%$ heat-inactivated fetal bovine serum (FBS; Gibco-BRL, Gaithersburg, USA), 100 U/ $\mathrm{mL}$ of penicillin and $100 \mu \mathrm{g} / \mathrm{mL}$ of streptomycin. Recombinant viruses were propagated and titered in Sf- 9 cells. The PCV2 virus strain was kindly provided by Professor Chiu, National Pingtung University of Science and Technology, Taiwan. A PK-15 cell line free of PCV1 contamination was maintained in DMEM supplemented with $10 \%$ FBS. The PCV2 strain used for the in vitro virus neutralization test was propagated in PK-15 cells.

\section{Construction of novel baculovirus surface display vectors carrying multiple expression cassettes}

The detailed procedures to construct novel baculovirus surface display vectors with multiple expression cassettes was described previously [19, 20]. To construct the baculovirus surface display vector $\mathrm{pBacSC}$ [21], plasmid pBacCE was constructed using pFast-Bac DUAL [22]. Sequences coding gp64 SS, His6, multiple cloning sites (Xho I, Xba I, PstI, and EcoRI) localized between His6 and baculovirus gp64 CTD, and baculovirus gp64 TM were inserted into $\mathrm{pBacCE}$ and the resultant plasmid was named $\mathrm{pBacSC}$. The baculovirus surface display vector BacDual Display (BacDD)-EGFP was constructed previously [20] and used to create pBacDD-2Cap (d41), pBacDD-3Cap (d41), and pBacDD-4Cap (d41) constructs. The 41 amino acids at the $\mathrm{N}$-terminus of the PCV2 Cap is a nuclear localization signals (NLS) [23]. The first 41 amino acids at the N-terminus of the PCV2 Cap protein were deleted and the truncated Cap gene of PCV2 was constructed into the pBacSC vector. To construct the pBacSC-Cap $(\mathrm{d} 41)$ plasmid, the PCV2 Cap gene with a deletion of the first $123 \mathrm{bp}$ was amplified by PCR using prime pair PCV2-Cap(d41)-XhoI and PCV2Cap(d41)-PstI (accession number AY885225; Table 1) and subcloned into the XhoI/PstI sites of the pBacSC plasmid.

To generate the BacDD-Cap $(\mathrm{d} 41)$ plasmid, the Cap(d41)-gp64(TM-CTD) fragment from the pBacSCCap(d41) plasmid was excised by Xhol/KpnI digestion, and inserted into the $\mathrm{XhoI} / \mathrm{KpnI}$ sites in the pBacDDEGFP vector. To generate the $\mathrm{pBacDD}-2 \mathrm{Cap}(\mathrm{d} 41)$ plasmid, the PCV2 Cap gene with a deletion of the first 123 bp was amplified using prime pair PCV2-Cap(d41)NotI and PCV2-Cap(d41)-SalI (Table 1) and subcloned into the NotI/Sa1I sites of the pBacDD-Cap $(d 41)$ vector. To create the pBacDD-4Cap $(\mathrm{d} 41)$ plasmid, the GemT-easy-DD vector with two expression cassettes was 
Table 1 Primer pairs used in this study

\begin{tabular}{|c|c|c|c|c|c|}
\hline Primer name & Sequence in $5^{\prime}-3^{\prime}$ direction & Location (nt) & Accession number & Product name & Length (bp) \\
\hline Cap(d41)-Xhol (Forward) & $\begin{array}{l}\text { Xhol } \\
\text { AGCCTCGAGATGACGTATCCAAGG }\end{array}$ & $124-702$ & AY885225 & Cap $(d 41)$ & 579 \\
\hline Cap(d41)-BsiWI (Reverse) & $\begin{array}{l}\text { Pstl } \\
\text { TCATCTGCAGTGAGGGTTTAA GTG }\end{array}$ & & & & \\
\hline Cap-(d41)-Notl (Forward) & $\begin{array}{l}\text { Notl } \\
\text { GCGGCCGCTATGAATGGCATC TTCAACACC }\end{array}$ & $124-702$ & AY885225 & Cap $(d 41)$ & 579 \\
\hline Cap(d41)-Sall (Reverse) & $\begin{array}{l}\text { Sall } \\
\underline{\text { GTCGACTATGGGTTTAAGTGG GGGGTC }}\end{array}$ & & & & \\
\hline Cap(d41)-Xhol (Forward) & $\begin{array}{l}\text { Xhol } \\
\text { CTCGAGATGAATGGCATCTTC AACACC }\end{array}$ & $124-702$ & AY885225 & Cap $(d 41)$ & 579 \\
\hline Cap(d41)-BsiWI (Reverse) & $\begin{array}{l}\text { BsiWI } \\
\text { CGTACGTATGGGTTTAAGT GGGGGGTC }\end{array}$ & & & & \\
\hline
\end{tabular}

constructed as described previously [20]. Two restriction enzyme sites MluI and BsiwI were included in this vector as described previously [20]. To construct the pGemT-easy-DD-2Cap(d41) plasmid, pBacDD-2Cap(d41) was digested with KpnI and HindIIII to obtain the Cap(d41)gp64(TM-CTD) fragment. The resultant fragment was then subcloned into the multiple cloning sites (KpnI and Hind III) of the pGem-T-easy-DD vector.

To construct the pBacDD-4Cap $(\mathrm{d} 41)$ plasmid containing four expression cassettes, two expression cassettes containing the Cap $(\mathrm{d} 41)$ gene from the pGemT-easy-DD-2Cap(d41) plasmid were digested by MluI and BsiWI, and the generated fragment was inserted into the corresponding sites of the pBacDD-2Cap $(d 41)$ plasmid. To construct the pBacDD-3Cap(d41) plasmid, pBacDD-4Cap(d41) plasmid was digested with BstZ17I to remove one expression cassette. The completed vector was named pBacDD-3Cap (d41).

Preparation of recombinant bacmid DNA and construction of recombinant baculoviruses

The resultant constructs pBacSC-Cap(d41), pBacDD2Cap(d41), pGem-T-easy-DD-2Cap(d41), pBacDD$3 \mathrm{Cap}(\mathrm{d} 41)$, and $\mathrm{pBacDD}-4 \mathrm{Cap}(\mathrm{d} 41)$ were verified by enzyme digestion and DNA sequencing (Figures 1B, 3A). Competent DH10Bac E. coli were then transformed with these recombinant plasmids and the non-recombinant plasmid pBacCE, respectively. The non-recombinant $\mathrm{pBacCE}$ was used as a negative control. After two rounds of blue/white selection, recombinant bacmids were isolated from white colonies according to the manufacturer's instructions (Invitrogen, Carlsbad, USA). The recombinant clones were then examined for the presence of the insert by PCR using Cap(d41) specific primers (Table 1). Positive colonies were cultured in order to isolate the bacmid DNA. Sf- 9 cells were cultured at $27^{\circ} \mathrm{C}$ in Sf-900 II SFM. $9 \times 10^{5}$ cells were seeded in $35-\mathrm{mm}$ wells

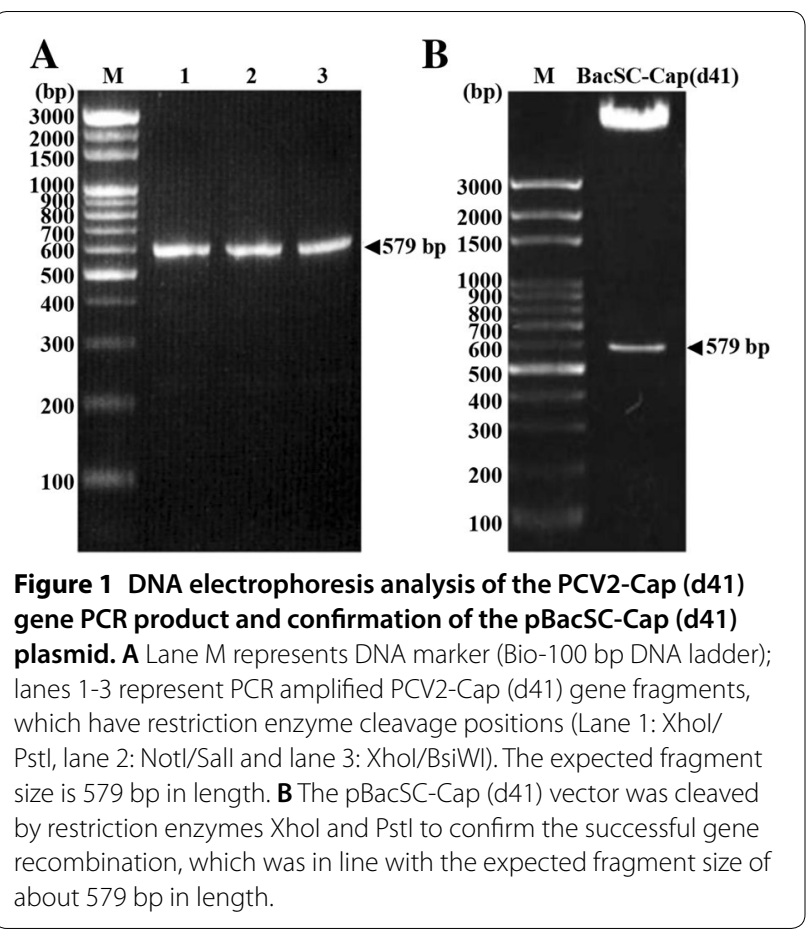

of a six-well plate and allowed to attach for $1 \mathrm{~h}$ before transfection. Transfected Sf- 9 cells were incubated for $5 \mathrm{~h}$ at $27{ }^{\circ} \mathrm{C}$ and replaced with fresh medium. After incubation for $48 \mathrm{~h}$ at $27^{\circ} \mathrm{C}$, recombinant viruses were selected based on GFP expression and purified by three rounds of plaque isolations. Individual recombinant viruses were titered by plaque assay and high titer stocks were utilized for infecting the cells.

\section{Sodium dodecyl sulfate polyacrylamide gel} electrophoresis (SDS-PAGE) and western blot assays Infected cell lysates were subjected to $12 \%$ SDS-PAGE and transferred to nitrocellulose membranes. Two 
primary antibodies were used to detect the Cap $(\mathrm{d} 41)$ protein by western blot. Expressed proteins were probed by anti-PCV2 sera for the Cap(d41) protein. The secondary antibody for the reaction was anti-mouse IgG conjugated to HRP (1:3000 dilution, Invitrogen). Protein bands were visualized using the ECL chemiluminescence kit (Amersham Pharmacia Biotech, New Territories, Hong Kong). Infected cell lysates were subjected to 10\% SDS-PAGE and transferred to nitrocellulose membranes. Two primary antibodies (anti-His6 monoclonal antibody 1:3000 dilution and anti-CPV-2 polyclonal antibody 1:1000 dilution) were used to detect CPV VP2 protein by western blot. The secondary antibody was goat anti- mouse IgG conjugated to HRP (1:5000 dilution; KPL, Gaithersburg, Maryland, USA). The protein bands were visualized by the ECL chemiluminescence system on Hyper-Max films, as recommended by the manufacturer (Amersham Pharmacia Biotech, Hong Kong).

\section{Comparison of the expression levels of the PCV2 Cap(d41) protein by different recombinant baculoviruses and optimum conditions for production of the PCV2 Cap(d41) protein}

To compare the expression levels of Cap(d41) expressed by different genetic recombinant baculovirus, $10^{7} \mathrm{Sf}-9$ cells were cultured in a 24-well plate, and then individually infected with recombinant baculoviruses BacSCCap(d41), BacDD-2Cap(d41), BacDD-3Cap(d41), and BacDD-4Cap(d41) at an MOI of 5, respectively. After 3 days of infection, cell lysates were collected and the expression levels of the PCV2 4Cap(d41)protein were analyzed by western blot assays.

To increase expression levels of the Cap (d41) protein, optimum conditions for recombinant baculovirus transfection were examined. In this work, various MOI $(1,5$, and $10 \mathrm{MOI})$, infection times (2-4 days), and different cell numbers $\left(10^{5}, 10^{6}\right.$, and $\left.10^{7}\right)$ for culture of recombinant baculoviruses BacSC-Cap(d41), BacDD-2Cap (d41), pBacDD-3Cap (d41), and pBacDD-4Cap (d41) were tested. As mentioned above, Sf-9 cells were grown at $27{ }^{\circ} \mathrm{C}$ in Grace's insect media (Invitrogen) supplemented with $10 \%$ heat inactivated FBS (Gibco-BRL), $100 \mu \mathrm{g} / \mathrm{mL}$ of penicillin and $100 \mu \mathrm{g} / \mathrm{mL}$ of streptomycin. After 3 days of infection, cells were collected and analyzed by western blot assays. To further examine the efficacy of the immune response with different immunogens, different numbers $\left(10^{5}, 10^{6}\right.$ and $\left.10^{7}\right)$ of Sf- 9 cells were infected with the recombinant baculoviruses BacDD-4Cap (d41) and BacSC-Cap (d41) at an MOI of 10 for 3 days, respectively. The respective cell lysates were used to prepare Cap $(\mathrm{d} 41)$ and $4 \mathrm{Cap}(\mathrm{d} 41)$ vaccines to immune mice. The immune experiments were divided into 6 groups $(\mathrm{n}=5$ for each group). These groups included the negative control group
(PBS and CE), positive control group (commercial porcine circovirus vaccine, Ingelvac ${ }^{\circledR}$ Circo FLEXTM), and experimental groups (BacDD-Cap (d41) and BacDD4Cap (d41) vaccines). Mice were immunized by the above vaccines via intraperitoneal injection. The same volume of complete adjuvant (Freund's adjuvant complete adjuvant) and the respective cell lysates (BacCE, BacDDCap(d41), and BacDD-4Cap(d41) were mixed in the first immunization and incomplete adjuvant was used in the second immunization. Two weeks after the first immunization, the second dose was given. The days post immunization (days post vaccination; dpv) start from the first immunization, and blood samples were taken by tail blood collection in the fourth week after immunization and at 2 weeks after the booster. Blood samples were centrifuged at $3000 \mathrm{rpm}$ for $15 \mathrm{~min}$ at $4{ }^{\circ} \mathrm{C}$ to separate the serum, and the supernatant was stored at $-20^{\circ} \mathrm{C}$ for subsequent experiments. Antibody titers were measured by enzyme-linked immunosorbent assay (ELISA).

To establish an ELISA for detection of the PCV2 Cap(d41) antibody, the optimal dilutions of antigen and serum were determined by checker board titration with PCV2-positive and -negative swine sera [24]. For expression of Cap(d41) in E. coli, the PCV2 Cap gene with a deletion of the first $123 \mathrm{bp}$ was amplified by PCR using prime pair PCV2-Cap(d41)-XhoI and PCV2-Cap(d41)PstI (Table 1) and subcloned into the expression vector pET32a. The procedures for expression of Cap $(\mathrm{d} 41)$ in $E$. coli have been described previously $[25,26]$. Briefly, the recombinant plasmid was transformed into $E$. coli BL21(DE3). The transformed E. coli cells were grown in Luria-Bertani (LB) broth with $100 \mu \mathrm{g} / \mathrm{mL}$ of ampicillin at $37^{\circ} \mathrm{C}$ to an optical density of 0.6 and then induced with $0.4 \mathrm{mM}$ of IPTG for $5 \mathrm{~h}$ at $28{ }^{\circ} \mathrm{C}$. Cells were harvested by centrifugation, followed by resuspension in pET system lysis buffer $(20 \mathrm{mM}$ Tris $-\mathrm{HCl} \mathrm{pH} 8,300 \mathrm{mM} \mathrm{NaCl}$, $0.2 \mathrm{mM}$ PMSF, $10 \%$ glycerol, $5 \mathrm{mM}$ imidazole) and sonicated. Cell suspensions were centrifuged at 12,000 $\times g$ for $20 \mathrm{~min}$ at $4{ }^{\circ} \mathrm{C}$. Each supernatant was applied to a nickel column. After washing beads with $150 \mathrm{~mL}$ washing buffer, TrxA-His-tagged Cap(d41) fusion proteins were eluted from the affinity column with elution buffer (20 mM Tris- $\mathrm{HCl} \mathrm{pH} 8,300 \mathrm{mM} \mathrm{NaCl}, 0.2 \mathrm{mM}$ PMSF, $10 \%$ glycerol, $200 \mathrm{mM}$ imidazole). Finally, purified fusion proteins were changed to PBS buffer with Amicon Ultra $0.5-\mathrm{mL} 10 \mathrm{k}$ filters (Millipore). Samples were stored at $-80{ }^{\circ} \mathrm{C}$ for further ELISA experiments. After adding the purified Cap $(\mathrm{d} 41)$ protein to the coating buffer, $100 \mu \mathrm{L}$ was added into each well and incubated at $4{ }^{\circ} \mathrm{C}$ for $16 \mathrm{~h}$. Each well of the plates was coated with the Cap $(\mathrm{d} 41)$ protein $(50 \mathrm{ng})$ in $100 \mu \mathrm{L}$ of coating buffer at $4{ }^{\circ} \mathrm{C}$ for $18 \mathrm{~h}$. After that, the coating buffer was removed, $100 \mu \mathrm{L}$ of blocking buffer ( $5 \%$ skim milk) was added to each well 
and incubated at room temperature for $1 \mathrm{~h}$. After washing three times with PBS (containing 0.1\% Tween 20), $100 \mu \mathrm{L}$ of serum samples were diluted and added into each well and incubated for $1 \mathrm{~h}$ at $37^{\circ} \mathrm{C}$. The plates were washed with PBS three times. For detection of the bound antibodies, $100 \mu \mathrm{L}$ of goat-anti-mouse IgG-HRP antibodies (KPL) were added and the plates were shaken at room temperature for $1 \mathrm{~h}$. Goat-anti-mouse IgG-horseradish peroxidase G-A-M IgG-HRP conjugate was used at a dilution of 1:5000. After washing with PBS 3 times, $100 \mu \mathrm{L}$ of ABTS solution was added to each well for $15 \mathrm{~min}$ in the dark and the reaction was stopped by adding $100 \mu \mathrm{L}$ of stop solution (20\% SDS) to each well to stop the color reaction. The $\mathrm{OD}_{405} \mathrm{~nm}$ value was measured with an ELISA reader.

\section{Immunization of SPF pigs and measurement of CPV Cap(d41) titers}

2-month-old SPF pigs were immunized at the base of the ear by the intramuscular route with $\mathrm{CE}, 4 \mathrm{Cap}(\mathrm{d} 41)$, and commercial vaccines, respectively. The pig serum was collected every week after the first immunization. In the eighth week after the first immunization, all vaccinated pigs were intranasally injected with $2 \mathrm{~mL}$ of PCV2 $\left(10^{5.7} \mathrm{TCID}_{50} / \mathrm{mL}\right)$. Sera samples were collected at 14 and 28 days after primary immunization for virus neutralization tests. Peripheral blood mononuclear cells (PBMCs) were isolated from the whole blood of immunized swine for lymphocyte proliferation assay at 42 days after primary immunization. The sera were used for examination of the ELISA titer. The sera were tested for the presence of Cap antibody titers using PCV2 antibody detection ELISA kit. All swine was confirmed without antibodies against PCV2 before used.

\section{Virus neutralization test}

To prepare the vaccines, $5 \times 10^{7} \mathrm{Sf}-9$ cells were infected with the recombinant baculoviruses BacSC-4Cap(d41) and BacCE at an MOI of 10 for 3 days, respectively, and the cell lysates were collected to prepare the $4 \mathrm{Cap}(\mathrm{d} 41)$ and $C E$ vaccines. To examine neutralizing antibody titers in vaccinated pigs and mice, the immune experiments were divided into three groups $(n=3$ for each group). These groups include the negative control group $\mathrm{CE}$, commercial porcine circovirus vaccine (Ingelvac ${ }^{\circledR}$ Circo FLEXTM), and 4Cap (d41) vaccine. The mice were immunized with the respective vaccines by intraperitoneal injection. The pigs were immunized with the respective vaccines formulated with ISA201by intramuscular injection. Two weeks after the first immunization, the second dose was given. PCV2 neutralizing titers of vaccinated pigs and mice were determined at 14 and 28 days or 35 days after primary vaccination. PCV2 neutralizing titers of vaccinated mice were detected at 35 days after primary vaccination.

To carry out the virus neutralization test, PK-15 cell lines $\left(10^{4}\right.$ cells/well) were cultured in 96 -well plates. Briefly, sera $(50 \mu \mathrm{L})$ from mice 35 days after vaccination were diluted in in twofold increments in DMEM medium ( $\mathrm{pH}$ 7.0), starting with a dilution factor of 1:2. An equal volume of PCV2 $\left(200 \mathrm{TCID}_{50}\right)$ was added to the serum samples and incubated at $37{ }^{\circ} \mathrm{C}$ for $1 \mathrm{~h}$. The mixed solution (serum and PCV2 virus) was then inoculated into a 96-well plate containing $40-50 \%$ confluent PK-15 cells for $72 \mathrm{~h}$. After washing three times by PBS, 90\% acetone was added to each well at $-20{ }^{\circ} \mathrm{C}$ for $30 \mathrm{~min}$, and the acetone was removed and wells were washed with PBS for 3 times. The culture plate was fixed with 90\% acetone, dried and incubated with porcine anti-PCV2 polyclonal antibodies, followed by staining with the FITC-conjugated goat anti-porcine IgG (Invitrogen). Titers were determined as the reciprocal of the last serum dilution with $70 \%$ or greater fluorescent focus reduction in the infected cells under a fluorescent microscope. Finally, the neutralizing antibody titers were calculated by the ReedMuench method [27].

\section{Lymphocyte proliferation assay}

The lymphocyte proliferation assay was performed using peripheral blood mononuclear cells (PBMCs) of swine. PBMCs were isolated from the whole blood of immunized swine with a lymphocyte separation medium. After washing three times with PBS, the PBMCs were resuspended at $10^{6}$ cells $/ \mathrm{mL}$ in RPMI-1640 supplemented with $10 \%$ FBS, and seeded in 96-well flat-bottom plates at $100 \mu \mathrm{L}$ per well. Experimental groups were divided into commercial vaccine $(10 \mu \mathrm{L}), 4 \mathrm{Cap}(\mathrm{d} 41)$, and the negative control $\mathrm{CE}$. These vaccines were added into the respective well and placed in a $37{ }^{\circ} \mathrm{C}$ incubator for $68 \mathrm{~h}$ followed by addition of $10 \mu \mathrm{L}$ of MTT (3-(4,5-cimethylthiazol-2-yl)-2,5-diphenyl tetrazolium bromide; $5 \mathrm{mg} / \mathrm{mL}$ per well) in a $37^{\circ} \mathrm{C}$ incubator for $4 \mathrm{~h}$. Finally, the reaction was terminated by adding $100 \mu \mathrm{L}$ of DMSO. The optical density (OD) was determined at $490 \mathrm{~nm}$, and the stimulation index (SI) was calculated as follows: $\mathrm{SI}=$ mean $\mathrm{OD}$ of PCV2 stimulated cells/mean OD of unstimulated cells.

\section{Detection of $\mathrm{CD}^{+}$and $\mathrm{CD}^{+}$analysis of immunized pig PBMC cells by flow cytometry}

At the sixth week after the first immunization, sera was collected to isolate PBMCs of each group of immunized pigs. After washing three times with PBS buffer, $10^{6}$ cells of $\mathrm{PBMC}$ were divided into $1.5 \mathrm{cc}$ centrifuge tubes. FITC mouse anti-pig CD4a monoclonal antibody and PE mouse anti-pig CD8a monoclonal antibody (BD 
Biosciences, San Jose, USA) were added. The reaction was carried out in the dark at $4{ }^{\circ} \mathrm{C}$ for $30 \mathrm{~min}$. After washing once, the cells were resuspended in PBS and analyzed by flow cytometry (BD FACSCalibur, USA). The percentages of $\mathrm{CD} 4{ }^{+}$and $\mathrm{CD} 8{ }^{+}$and the $\mathrm{CD} 4^{+} / \mathrm{CD}^{+}$ratio of PBMC cells were analyzed.

\section{Analysis of IFN- $\gamma$ and IL-4 by ELISA}

Analysis of IFN- $\gamma$ and IL-4 by ELISA was performed using the IFN- $\gamma$ and IL-4 ELISA Kit (Uscn, USA), and murine IFN- $\gamma$ ELISA KIT (Gen-Probe, San Diego, USA). Firstly, $100 \mu \mathrm{L}$ of pig serum or mouse serum were added to the ELISA plates with pre-coated monoclonal antibody at $37^{\circ} \mathrm{C}$ for $2 \mathrm{~h}$. After washing with PBS three times, the plates were blocked with complete RPMI medium containing $10 \%$ fetal bovine serum (FBS) for $2 \mathrm{~h}$ at $37{ }^{\circ} \mathrm{C}$. Finally, $100 \mu \mathrm{L}$ of streptavidin-HRP was added to each well for $20 \mathrm{~min}$ at room temperature. After washing 3 times, $100 \mu \mathrm{L}$ of $3,3^{\prime}, 5^{\prime}, 5^{\prime}$-tetramethylbenzidine (TMB) coloring agent was added to each well. Finally, the color development was initiated by adding $100 \mu \mathrm{Ll}$ of TMB buffer $(100 \mu \mathrm{L} /$ well $)$ and terminated by adding $100 \mu \mathrm{L}$ of $\mathrm{H}_{2} \mathrm{SO}_{4}$. The $\mathrm{OD}_{405} \mathrm{~nm}$ value was measured with an ELISA reader.

\section{Swine challenge test and real-time quantitative PCR}

On the eighth week after the first immunization, all vaccinated pigs were intranasally injected with $2 \mathrm{~mL}$ of PCV2 $\left(10^{5.7} \mathrm{TCID}_{50} / \mathrm{mL}\right)$. DNA was extracted from serum samples (containing PCV2 DNA) and analyzed by realtime quantitative PCR [28]. The sequences of primers are as follow: P5: $5^{\prime}$-GCTGAACTTTTGAAAGTGAGC GGG-3', P6: 5'-TCAC ACAGTCTCAGTAGATCAT CCCA-3'. The expected size of PCR product is $220 \mathrm{bp}$ in length. The PCR amplified products were ligated into the pGEM-T easy vector, and then transformed into $E$. coli DH5 $\alpha$. Colonies were screened with Amp ${ }^{+}$, the DNA was extracted and amplified, the plasmid DNA concentration was measured, and the plasmid DNA was diluted tenfold into six gradients. As a standard, real-time fluorescent quantitative PCR was used to prepare a standard curve. Finally, the DNA samples extracted every week were analyzed by real-time quantitative PCR. The reaction volume was $20 \mu \mathrm{L}$, consisting of $10 \mu \mathrm{L}$ of $2 \mathrm{X}$ QuantiFast SYBR Green PCR Master Mix, $2 \mu \mathrm{L}$ of P5 primer $(10 \mu \mathrm{M} / \mu \mathrm{L})$, $2 \mu \mathrm{L}$ of P6 primer $(10 \mu \mathrm{M} / \mu \mathrm{L}), 2 \mu \mathrm{L}$ of DNA template and $5 \mu \mathrm{L}$ of RNase-free water. The reaction conditions were $95^{\circ} \mathrm{C}$ for $5 \mathrm{~min}, 95^{\circ} \mathrm{C}$ for $10 \mathrm{~s}, 60^{\circ} \mathrm{C}$ for $1 \mathrm{~min}$, for a total of 30 cycles, and an analysis curve was prepared after the reaction.

\section{Statistical analysis}

All data were analyzed using independent sample $t$ test and are expressed as averages of three independent experiments. A P value less than 0.05 was considered significant.

\section{Results \\ Amplification of the PCV2 Cap(d41) gene and construction of pBacSC-Cap (d41) plasmid}

In this study, the PCV2 Cap gene with deletion of the first 123 bp was amplified by PCR. The expected size of the PCR products is $579 \mathrm{bp}$ in length (Figure 1A). The resulting gene is named Cap $(\mathrm{d} 41)$. The PCR product was subcloned into the restriction sites of $\mathrm{XhoI}$ and PstI in the baculovirus surface display vector (pBacSC) [21] and the resultant plasmid was named as pBacSCCap(d41) (Figure 1). To further confirm the recombinant pBacSC-Cap(d41) plasmid contained the PCV2 Cap(d41) gene, this vector was digested with restriction enzymes XhoI and PstI. As shown in Figure 1B, the expected fragments are seen. The pBacSC-Cap $(\mathrm{d} 41)$ plasmid was also sequenced to confirm their authenticity. To improve the recombinant virus selection, enhanced green fluorescent protein (EGFP) coding sequences were subcloned into the corresponding site in plasmid BacSC under the strong viral polyhedron (polh) promoter (Figure 2A).

\section{Construction of novel baculovirus surface display vectors carrying multiple expression cassettes for high level expression of the PCV2 Cap(d41) protein}

In this study, baculovirus surface display vectors pBacDD-EGFP and pGem-T-easy-DD were constructed as described previously [20]. These vectors were used to create pBacDD-2Cap(d41), pBacDD-3Cap(d41), and pBacDD-4Cap(d41) constructs (Figure 2B-D). Three recombinant baculoviruses BacDual Display (BacDD)2Cap(d41), BacDD-3Cap(d41), and BacDD-4Cap(d41) were further created to express His6-tagged Cap (d41) (with C-terminal gp64 TM-CTD). The resultant pBacSCCap (d41), pBacDD-2Cap(d41), pBacDD-3Cap(d41), and $\mathrm{pBacDD}-4 \mathrm{Cap}(\mathrm{d} 41)$ plasmids were used to generate BacSC-Cap (d41), BacDD-2Cap(d41), BacDD-3Cap(d41), and BacDD-4Cap $(\mathrm{d} 41)$ recombinant baculoviruses using the Bac-to-Bac system (Invitrogen). To further confirm that these recombinant pBacDD-2Cap(d41), pBacDD$3 \mathrm{Cap}(\mathrm{d} 41)$, and $\mathrm{pBacDD}-4 \mathrm{Cap}(\mathrm{d} 41)$ plasmids contained the PCV2 cap $(\mathrm{d} 41)$ gene, these vectors were digested with the respective restriction enzymes. As shown in Figure 3A, the expected fragments are seen. These vectors were also further sequenced to confirm their authenticity. Fluorescence images of Sf-9 cells infected with BacSC-Cap (d41), BacDD-2Cap(d41), BacDD-3Cap(d41), and BacDD-4Cap(d41) recombinant baculoviruses at 


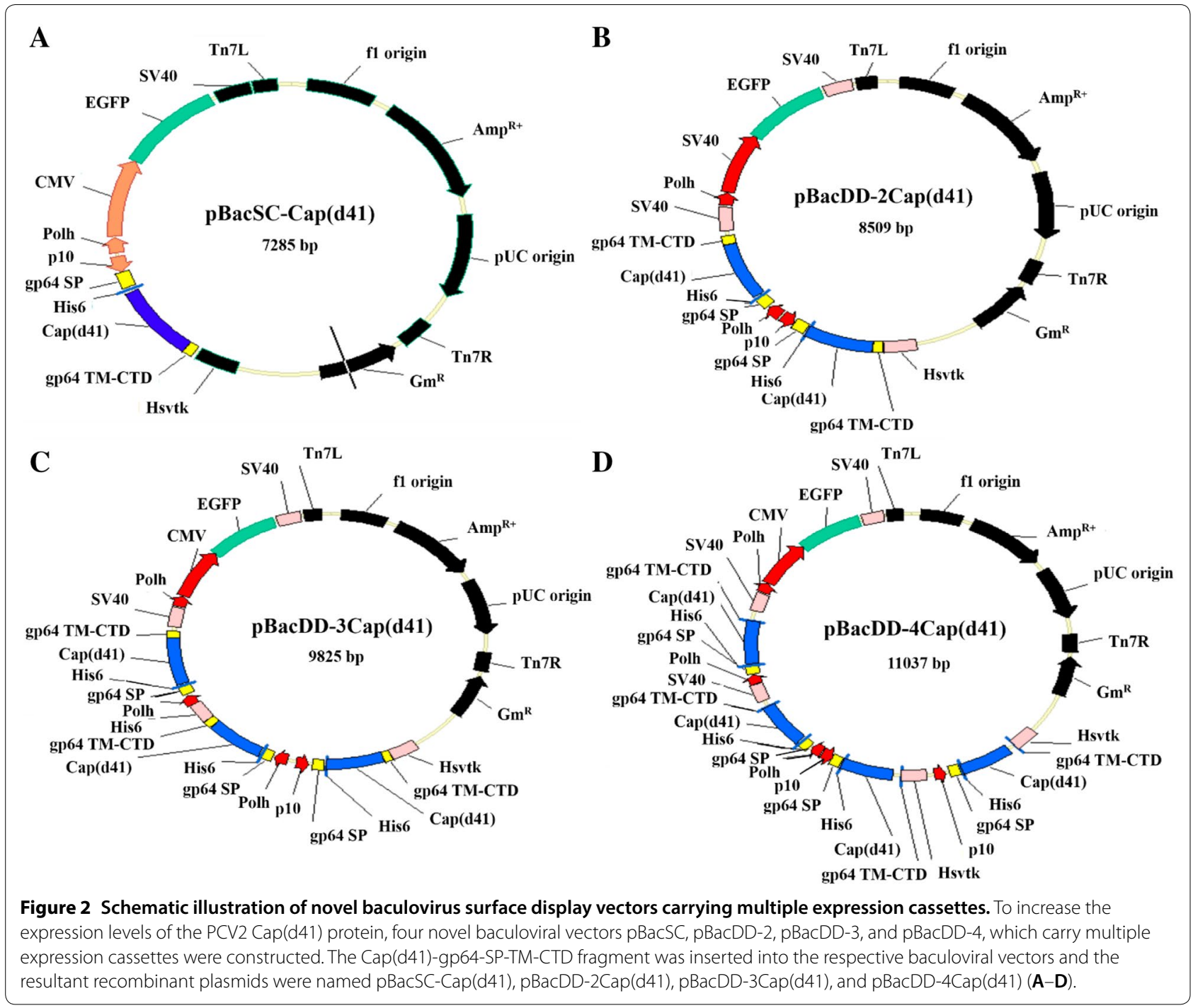

3 days post-infection are shown in Figure 3B. By comparing the expression levels of the PCV2 Cap $(\mathrm{d} 41)$ proteins by different recombinant baculovirus, we found that the recombinant baculovirus $\mathrm{BacDD}-4 \mathrm{Cap}(\mathrm{d} 41)$ was able to express higher levels of the Cap $(\mathrm{d} 41)$ protein than other recombinant baculoviruses (Figure $3 \mathrm{C}$ ). Our results reveal that the protein expressed by the recombinant baculovirus display system can not only present on the cell membrane but also exist in the cytoplasm.

\section{Optimum conditions for production of the PCV2 Cap(d41) protein}

To increase the expression/display levels of the PCV2 Cap(d41) protein, the optimum conditions for recombinant baculovirus transfection and cell growth were tested. As shown in Figure 4A, the conditions of an MOI of 10 and 4 day post infection have higher levels of PCV2 Cap(d41) protein expression while after 2 days of infection with insect cells, the PCV2 4 Cap $(d 41)$ protein was still not detected. Among the MOI tested, both 5 and 10 MOIs yield higher levels of protein expression and are the optimal conditions for protein expression (Figure 4B). Furthermore, production of the PCV2 Cap $(\mathrm{d} 41)$ protein in different cell numbers infected with recombinant baculovirus at an MOI of 10 was also examined. Our results reveal that higher levels of the PCV2 Cap $(\mathrm{d} 41)$ protein 
A

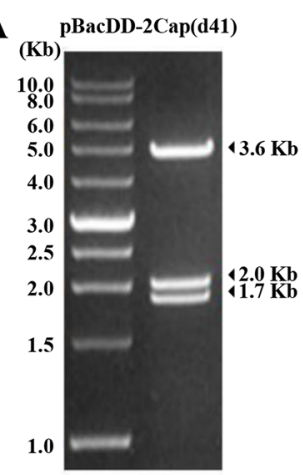

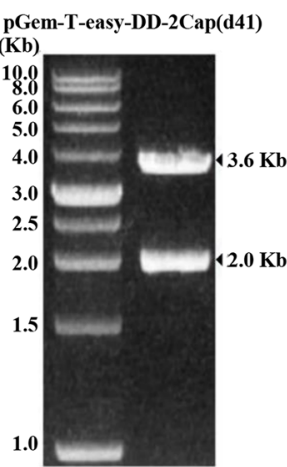
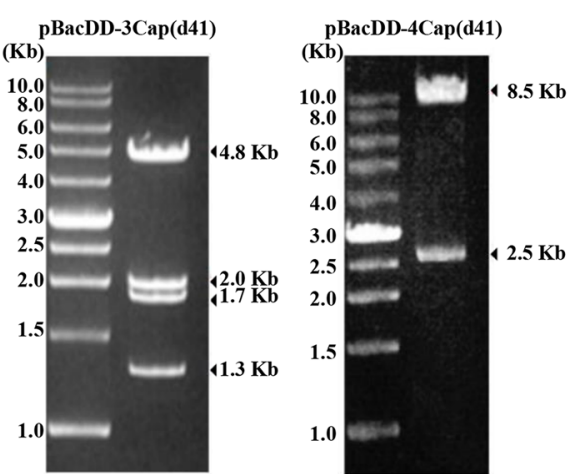

B
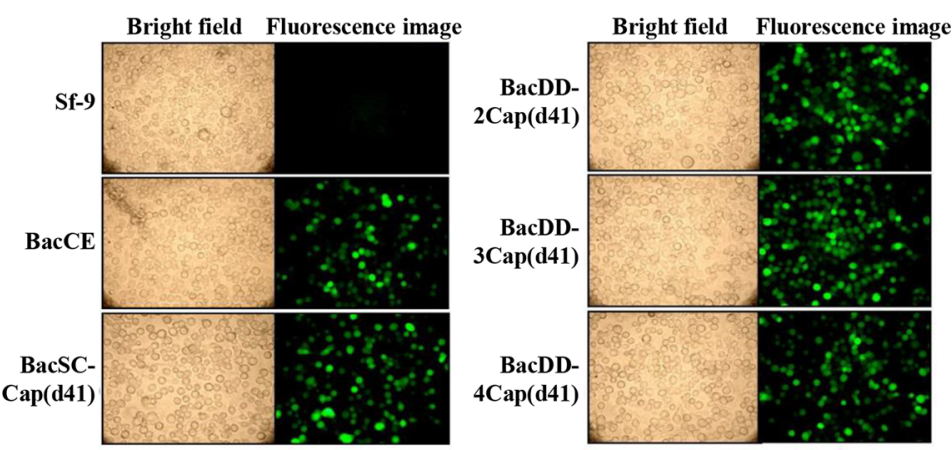

C
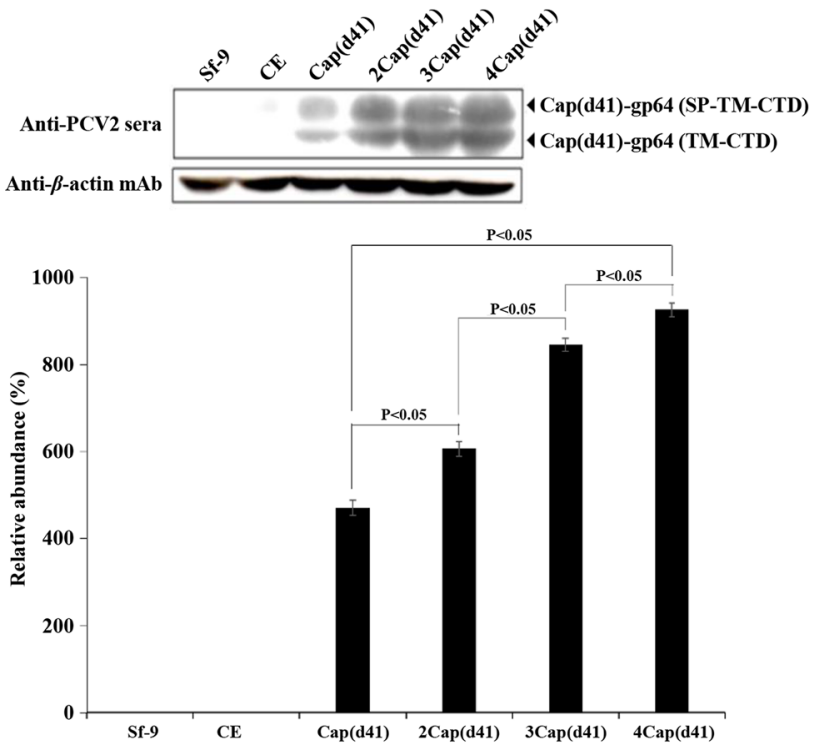

Figure 3 Confirmation of recombinant baculovirus surface vectors and expression levels of the Cap (d41) protein using the respective baculovirus surface vectors. A Four recombinant plasmids pBacDD-2Cap(d41), pGem-T-easy-DD-2Cap(d41), pBacDD-3Cap(d41), and pBacDD-4Cap(d41) were digested with the respective restriction enzymes for confirming the presence of the Cap(d41) gene of PCV2. B Images of BacSC-Cap(d41), BacDD-2Cap(d41), BacDD-3Cap(d41), and BacDD-4Cap(d41) recombinant baculovirus-infected Sf-9 cells at 3 days post-infection. All images were magnified at 200x. C Confirmation of the expression of Cap(d41)-gp64-TM-CTD protein in Sf-9 cells. The cells were infected with recombinant viruses BacCE, BacSC-Cap(d41), BacDD-2Cap(d41), BacDD-3Cap(d41), and BacDD-4Cap(d41), respectively, at an MOI of 10, harvested 3 days post infection, and subjected to western blot assay using anti-PCV2 sera (lanes 2-6). The Cap(d41) protein has two different fragments (Cap(d41)-gp64-SP-TM-CTD with a molecular weight of 33 kDa; Cap(d41)-gp64-TM-CTD with a molecular weight of 28 kDa. Sf-9 cells and BacCE were used as the negative control. Signals in all western blots were quantified using Image I software. The levels in the Cap(d41) were considered one-fold. $\beta$-actin was used as an internal control for normalization. The expression folds indicated below each lane were normalized against values for Cap(d41). Data represent the mean \pm SD. A p value less than 0.05 was considered significant. 
were seen in both BacDD-4Cap(d41) and $10^{7}$ cell numbers (Figure $4 \mathrm{C}$ ). Furthermore, we examined the immune effect of different doses of Cap (d41) protein and evaluated the effective dose. Different cell numbers $\left(10^{5}, 10^{6}\right.$ and $10^{7}$ ) of Sf-9 cells were infected with recombinant baculoviruses at an MOI of 10 for 3 days, respectively and the cell lysates were collected to immunize mice. After two vaccinations, the antibody was collected and analyzed by ELISA. The results confirmed that commercial vaccine and the PCV2 Cap(d41) protein expressed by the BacDD-4Cap(d41) recombinant baculovirus can effectively induce higher ELISA titers in mice (Figure 4D).

\section{Cap(d41) and commercial vaccines induced neutralizing antibody in mice and SPF pigs}

In this work, fluorescence staining was observed under a magnification of $200 \times$ under a fluorescent microscope (Figure 5A). The fluorescence results were converted into neutralizing antibody titers and presented as a data chart (Figure 5B). The results showed that neutralizing antibody titers induced by the commercial and 4Cap(d41) vaccines were $1: 11$ and $1: 14$, respectively. The virus neutralization titers of mice immunized with the commercial and $4 \mathrm{Cap}(\mathrm{d} 41)$ vaccines were much higher than those of the negative groups (CE and PBS). This result is consistent with the PCV2 neutralization titer 1:14 reported previously [29].

As shown in Figure 6, swine immunized with 4Cap $(\mathrm{d} 41)$ and commercial vaccines triggered PCV2 neutralizing antibody titers of 1:5.5 and 1:5 at 2 weeks after primary immunization, which increased further to $1: 22$ and 1:21 at 4 weeks post vaccination.

\section{Change of the ratio of $\mathrm{CD}^{+}$to $\mathrm{CD} 8^{+}$in pig PBMC cells}

To determine whether the 4Cap (d41) vaccine can cause $\mathrm{T}$ lymphocyte subsets in pigs, we collected PBMC cells from the blood of immunized pigs and analyzed them by flow cytometry. As shown in Table 2, the percentage of $\mathrm{CD}^{+} \mathrm{T}$ cells in the $4 \mathrm{Cap}(\mathrm{d} 41)$ group and the commercially available vaccine group was significantly higher than in the CE negative control group. The percentage of $\mathrm{CD}^{+} \mathrm{T}$ cells in $4 \mathrm{Cap}(\mathrm{d} 41)$ group and commercial vaccine group was significantly lower than in $\mathrm{CE}$ group. The ratio of $\mathrm{CD}^{+} / \mathrm{CD}^{+}$in $4 \mathrm{Cap}(\mathrm{d} 41)$ and commercial vaccine groups was significantly higher than that in the $\mathrm{CE}$ negative control group.

\section{Lymphocyte proliferative responses in swine immunized with different immunogens}

In the present study, we investigated whether the 4Cap (d41) vaccine can effectively induce cellular immune responses in pigs after two immunizations.
To investigate whether the pseudotyped baculovirus BacDD-4Cap(d41) can induce cell-mediated immune responses, the lymphocyte proliferative responses were examined at 42 days after primary immunization. As shown in Figure $7 \mathrm{~A}$, the SI value $(3.75 \pm 0.3)$ was significantly higher in swine immunized with the $4 \mathrm{Cap}(\mathrm{d} 41)$ vaccine than those immunized with commercial vaccine $(2.7 \pm 0.15)$ and the negative control CE $(1.4 \pm 0.1)$. The difference was statistically significant $(\mathrm{P}<0.05)$. These results suggested that the $4 \mathrm{Cap}(\mathrm{d} 41)$ vaccine prepared from genetic recombinant baculovirus BacDD4Cap(d41)-infected Sf-9 cells induced a remarkable cellular immune response in swine.

\section{Analysis of IFN- $\gamma$ in swine immunized with different immunogens}

A previous study showed that IFN- $\gamma$ is an important factor in the vaccine-induced cellular immune response [30]. Therefore, IFN- $\gamma$ was used as an indicator of cellular immunity in this study. It was confirmed by IFN- $\gamma$ ELISA that both 4Cap (d41) and commercially available vaccines can stimulate immune cells to secrete IFN- $\gamma$ and induce cellular immune responses (Figures 5C, 7B). Although 4Cap (d41) and the commercially available vaccine group produced IL-4, there was no significant difference compared to the negative group CE (Figure 7B).

\section{Analysis of the serum antibody level of pigs immunized with 4Cap (d41) and commercial vaccines}

In the group vaccinated with $4 \mathrm{Cap}(\mathrm{d} 41)$ and commercial vaccine, the antibody levels in the eighth week after the first immunization gradually increased to reach the highest $\mathrm{OD}_{405} \mathrm{~nm}$ of 0.7 and 0.62 , respectively, which was significantly different from the CE negative control group (Figure 8). The challenge test was conducted in the eighth week after the first immunization. The antibody levels of the $4 \mathrm{Cap}(\mathrm{d} 41)$ vaccine group, the commercial vaccine group, and the $\mathrm{CE}$ negative control group reached the highest $\mathrm{OD}_{405} \mathrm{~nm}$ of 1.0, 0.96 and 1.0 in the third week after challenge. These data indicate that the challenge in pigs will affect the increase in antibody levels.

\section{Quantitative analysis of PCV2 DNA in pig blood by real-time quantitative $P C R$}

In the third week after the challenge, the PCV2 viral load reached the highest level. The viral $\operatorname{load} \log _{10}$ of the 4Cap(d41) vaccine group was 2.11; the viral $\operatorname{load}_{\log }$ of the commercial vaccine group was 2.12 (Figure 9). In the seventh week after the challenge, the viral $\operatorname{load} \log _{10}$ of the $4 \mathrm{Ca}(\mathrm{d} 41)$ and commercial vaccine groups was 0.11 and 0.4 , respectively while the viral load of the CE negative control group was is 1.57 (Figure 9). 

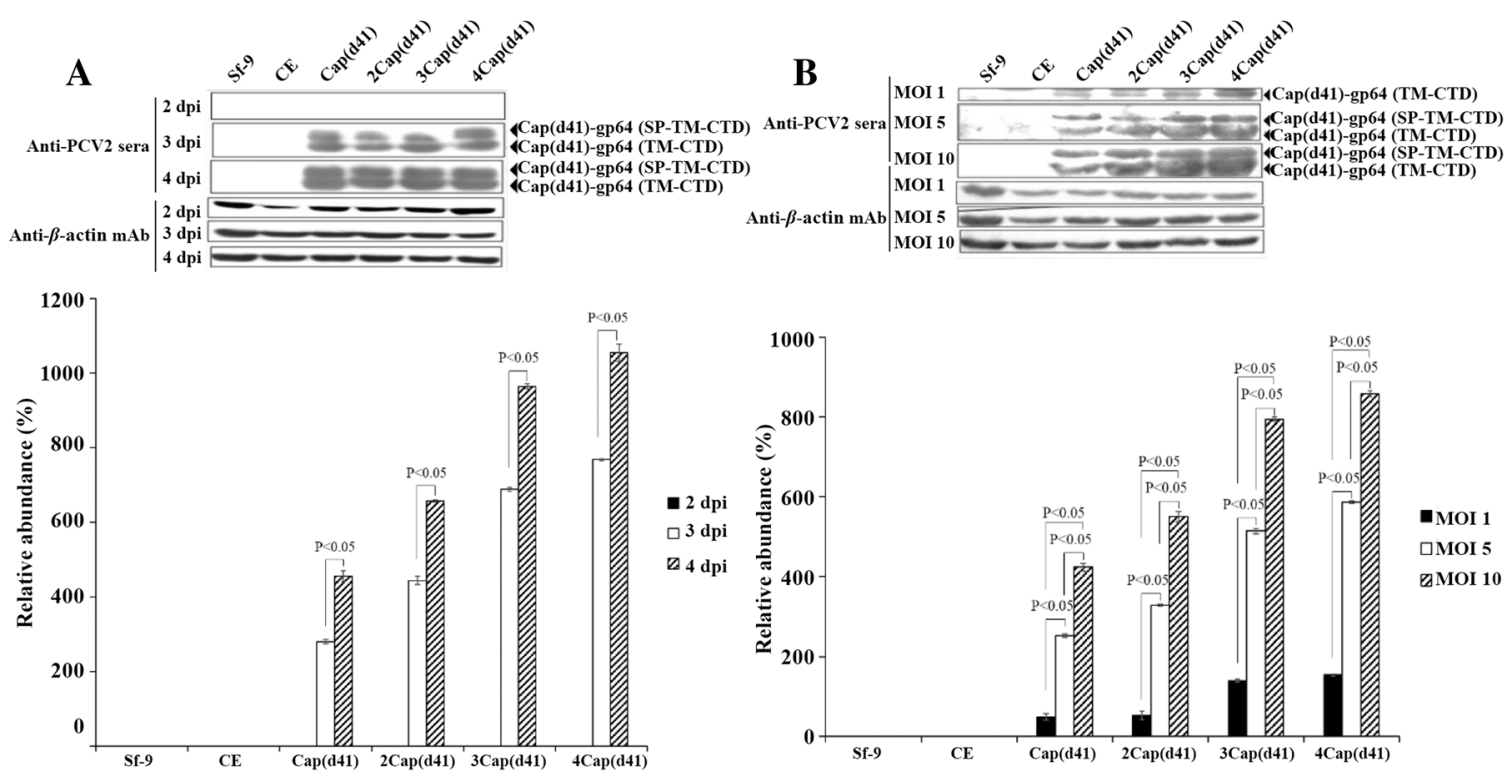

\section{C}

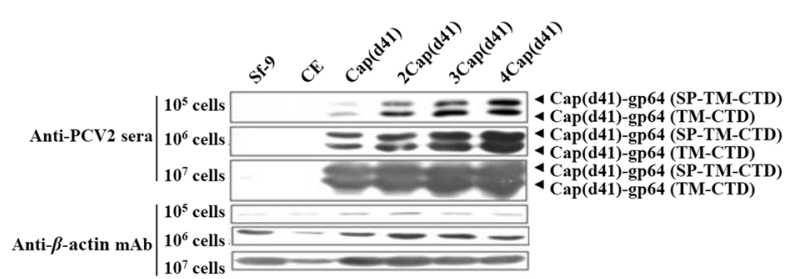

D
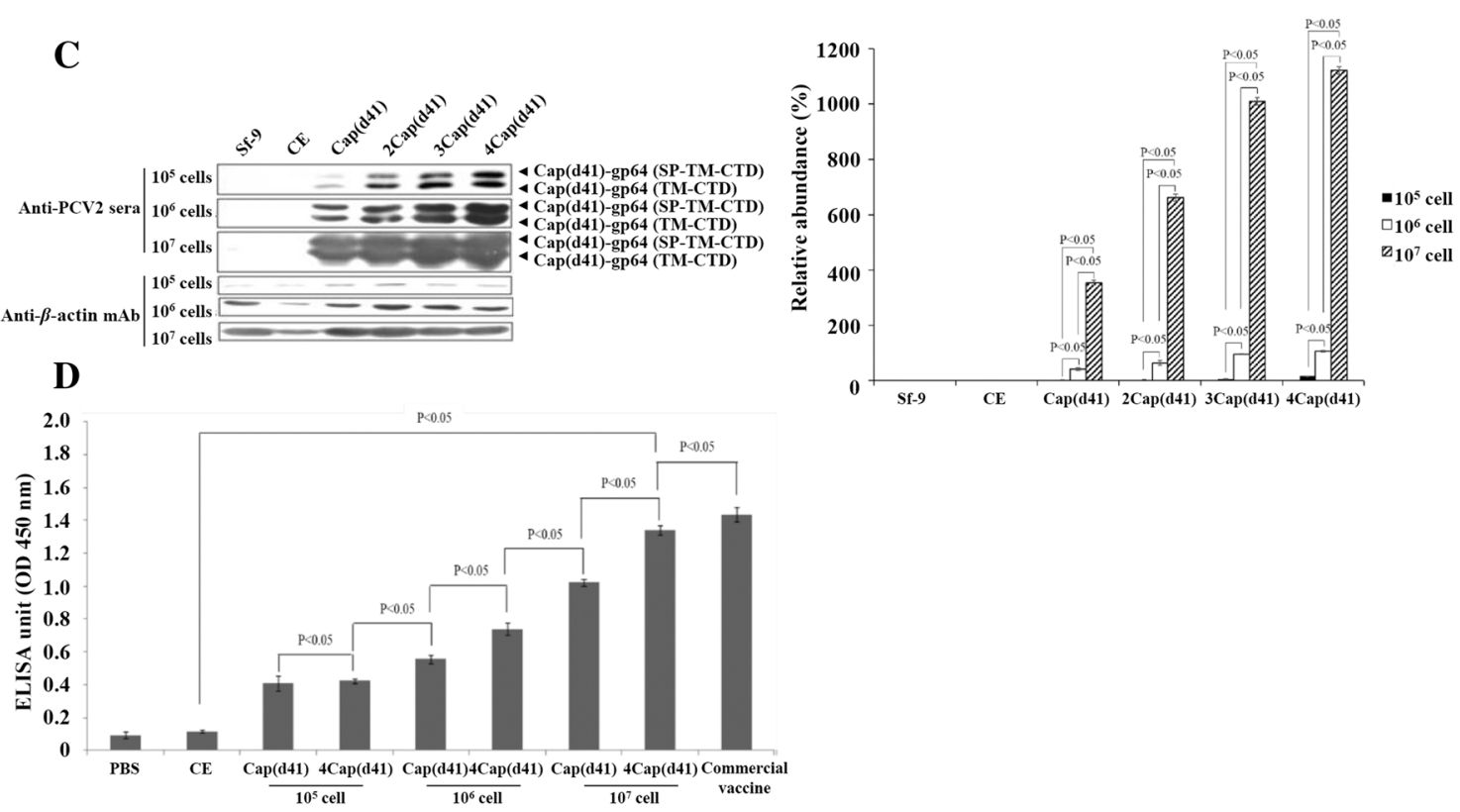

Figure 4 Optimum conditions for production of the PCV2 Cap(d41) protein. Effects of different infection times, MOI, and cell numbers for expressing the Cap(d41) protein were tested. A, B Cell numbers (10 $\left.{ }^{7}\right)$ of Sf-9 cells were infected with $\mathrm{MOl}$ of $10(\mathbf{A})$ or infected with different $\mathrm{MOI}$ (B) for 4 days. Cell numbers $\left(10^{7}\right)$ of Sf-9 cells were infected with different recombinant baculoviruses as indicated. The Sf-9 cell alone and CE recombinant baculoviruses were used as the negative control. Signals in all western blots were quantified using Image I software. $\beta$-actin was used as an internal control for normalization. Relative abundance (\%) are shown. The results were calculated from the data shown in the upper portion of each panel. All data shown represent the mean \pm SD calculated from three independent experiments. A student t-test was conducted for analysis and a value of $\mathrm{P}<0.05$ was considered statistically significant. $\mathbf{C}$ Expression levels of the PCV2 Cap(d41) protein in different cell numbers infected with recombinant baculovirus at an $\mathrm{MOI}$ of 10 for 4 days was examined. Signals in all western blots were quantified using Image I software. $\beta$-actin was used as an internal control for normalization. Relative abundance (\%) are shown. The results were calculated from the data shown in the left portion of each panel. All data shown represent the mean \pm SD calculated from three independent experiments. A student t-test was conducted for analysis and a value of $\mathrm{P}<0.05$ was considered statistically significant. $\mathbf{D}$ The immune effect of different doses of $\mathrm{Cap}(\mathrm{d} 41)$ protein and evaluation of the effective dose. Different cell numbers $\left(10^{5}, 10^{6}\right.$ and $\left.10^{7}\right)$ of Sf-9 cells were infected with recombinant baculoviruses BacSC-Cap(d41) and BacDD-4Cap(d41), respectively, at an MOI of 10 for 3 days, respectively and cell lysates were collected to immunize mice. After two vaccinations, antibody titers were analyzed by ELISA. Data represent the mean \pm SD. A p value less than 0.05 was considered significant. 


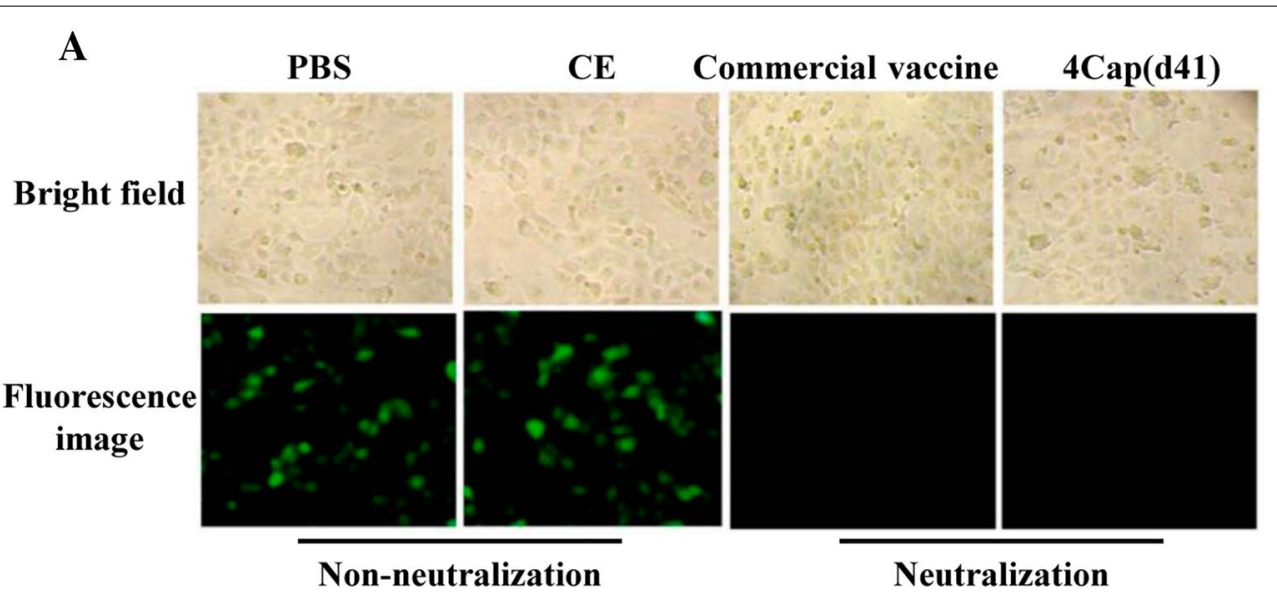

B

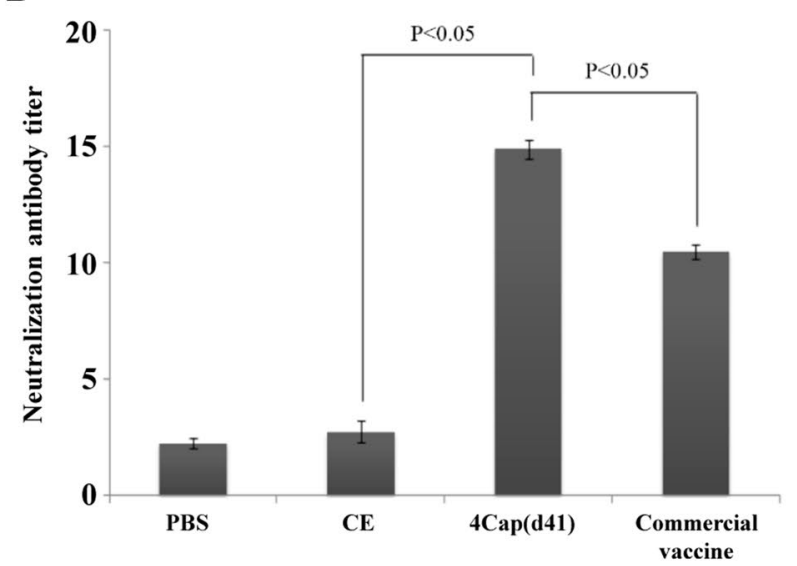

C

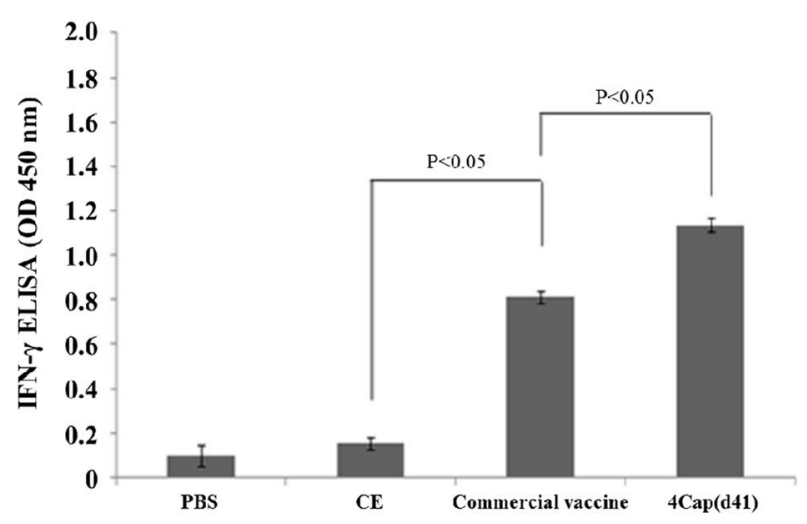

Figure 5 Serum neutralization (SN) titers and the level of IFN- $\gamma$ in mice immunized with various immunogens. A The SN titers in mice induced by $4 \mathrm{Cap}(\mathrm{d} 41)$ and commercial vaccines. $5 \times 10^{7} \mathrm{Sf}-9$ cells were infected with the recombinant baculovirus BacDD-4Cap (d41) at an MOI of 10 for 3 days. Cell lysates were collected to prepare the 4Cap(d41) vaccine. Eight-week-old mice were vaccinated via intraperitoneal injection at weeks 0 and 2 with PBS, CE, 4Cap (d41), and commercial vaccines as formulated with complete and incomplete adjuvants. As negative controls, three mice were injected with PBS and CE $\left(5 \times 10^{7}\right.$ BacCE-infected Sf-9 cell lysates). Each mouse received one booster shot in week 2, and blood samples were taken at week 5 for the SN titer assay. B The fluorescence results were converted into neutralizing antibody titers and presented as a data chart (B). Data represent the mean \pm SD. C Analysis of IFN- $\gamma$ by ELISA was performed using the IFN- $\gamma$ ELISA Kit. The value of OD $405 \mathrm{~nm}$ was measured with an ELISA reader. Data represent the mean \pm SD. A P value less than 0.05 was considered significant. 


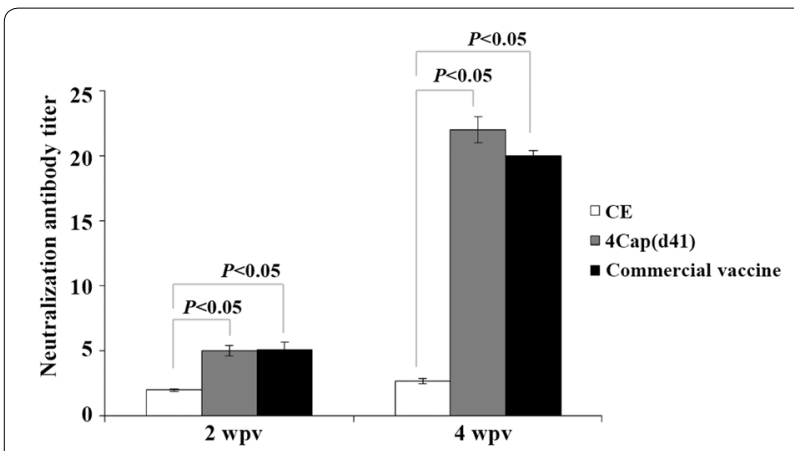

Figure 6 Serum neutralization (SN) titers in swine immunized with various immunogens. 2-month-old SPF pigs were immunized at the base of the ear by the intramuscular route with PBS, CE, 4Cap (d41) $(80 \mu \mathrm{g})$, and commercial vaccines, respectively. Sera samples were collected at 14 and 28 days after primary immunization for virus neutralization tests. Data represent the mean $\pm S D$. A P value less than 0.05 was considered significant

Table 2 Analysis of $\mathrm{CD}^{+}$and $\mathrm{CD8}^{+}$of immunized pig PBMC cells by flow cytometry

\begin{tabular}{lccc}
\hline Group & $\mathrm{CD4}^{+}(\%)$ & CD8 $^{+}(\%)$ & $\mathrm{CD}^{+} / \mathrm{CD}^{+}$ratio \\
\hline CE & $24.2 \pm 0.49$ & $5.9 \pm 0.93^{*}$ & $4.14 \pm 0.57$ \\
4Cap(d41) & $39.5 \pm 0.7^{*}$ & $1.5 \pm 0.04$ & $27.1 \pm 1.16^{*}$ \\
Commercial vaccine & $21.9 \pm 0.85$ & $1.2 \pm 0.04$ & $18.74 \pm 1.4^{*}$
\end{tabular}

The symbol $(*)$ shows statastical differences between $\mathrm{CE}$ group and experimental groups $(p<0.05)$

\section{Discussion}

PCV2 is a major infectious pathogen that causes PMWS, which is one of the most important swine diseases that causes significant economic losses worldwide. The PCV2 Cap protein is the major structural viral protein encoded by ORF2 and induces host-specific neutralizing antibody [4-6], which makes it an important target in the design of a subunit vaccine against PCV2 infections. Several studies have been conducted on PCV2 vaccines [31-37]. One previous study confirmed that the $\mathrm{N}$-terminal 47 amino acid is not related to the structure of the epitope [38], and its N-terminal 41 amino acids have been confirmed to contain a nuclear localization signal (nuclear localization signal; NLS), where the N-terminal 12-18 amino acid (RHRPRSH) and 34-41 amino acid (HRYR WRRK) fragments are regarded as important signals for transport to the nucleus [39]. Another report pointed out that the PCV2 Cap protein with NLS will be transported to the nucleus after translation. When this NLS is deleted, the Cap protein is retained in the cytoplasm $[23,39]$. To prevent the nuclear localization signals (NLS) of the Cap protein from affecting cell viability and Cap protein displayed on cell membranes by the baculovirus surface display system, the first 41 amino acids at the

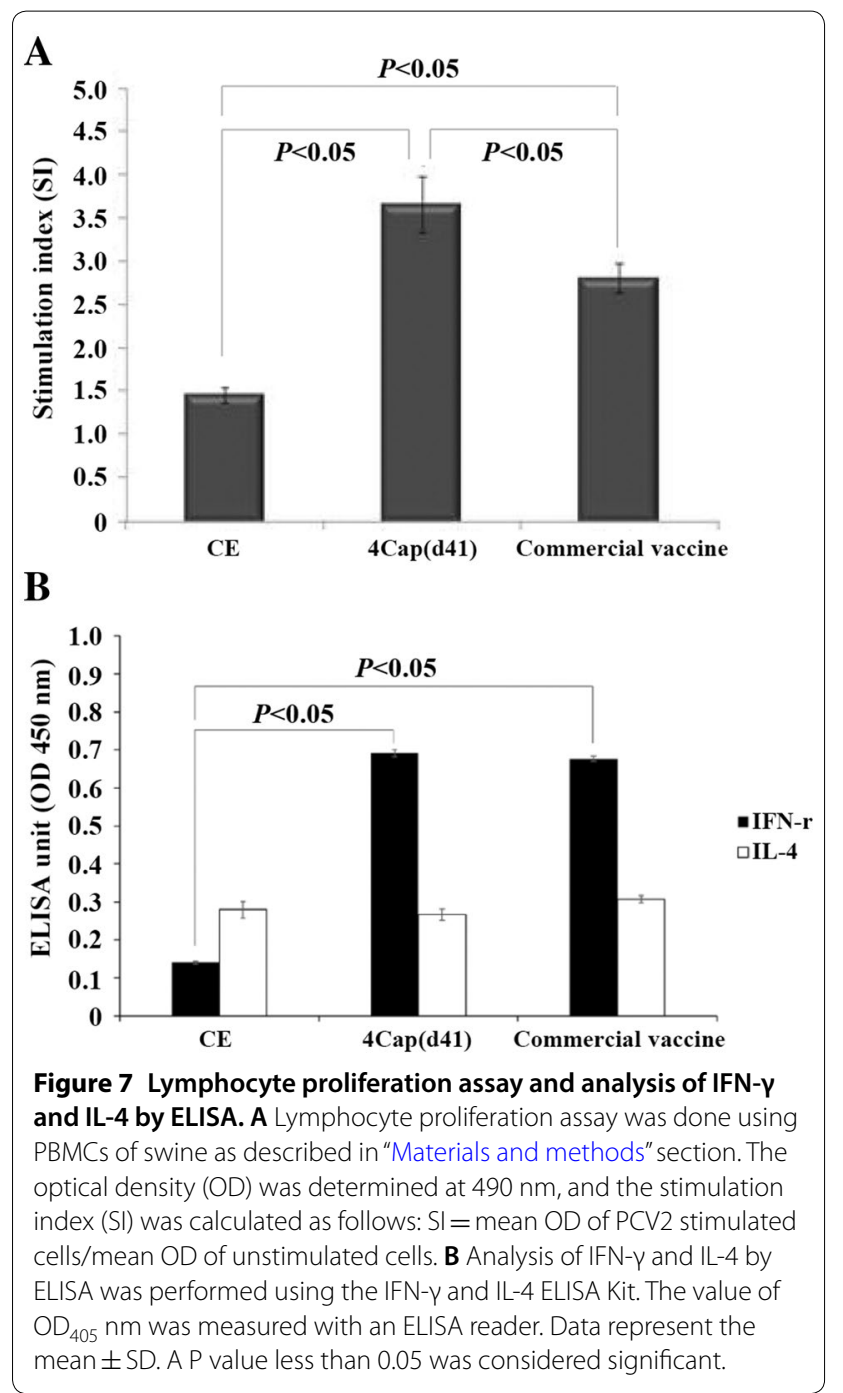

$\mathrm{N}$-terminus of the PCV2 Cap protein were deleted and the PCV2 Cap $(\mathrm{d} 41)$ protein was expressed/displayed on cell membranes. It was found that the Cap $(\mathrm{d} 41)$ protein contains two fragments with different molecular weights. In low MOI, low levels of the Cap(d41)-gp64 (SP-TMCTD) fusion protein was expressed and sent to the cell membrane, thus most of gp64 SP fragment has been excised from the Cap(d41)-gp64 (SP-TM-CTD) fusion protein. Thus only one major band (molecular weight $28 \mathrm{kDa}$ ) was seen. In the high MOI group, the higher levels of the Cap(d41)-gp64 (SP-TM-CTD) fusion protein were expressed. When the cell membrane with displayed protein has reached saturation, it may accumulate excess protein in the cytoplasm (molecular weight $33 \mathrm{kDa}$ ). Therefore, two bands were seen in the high MOI group.

The recombinant baculovirus surface display system has been exploited for the production of vaccines [20-22, $36,40,41]$. However, the higher costs of using eukaryotic 


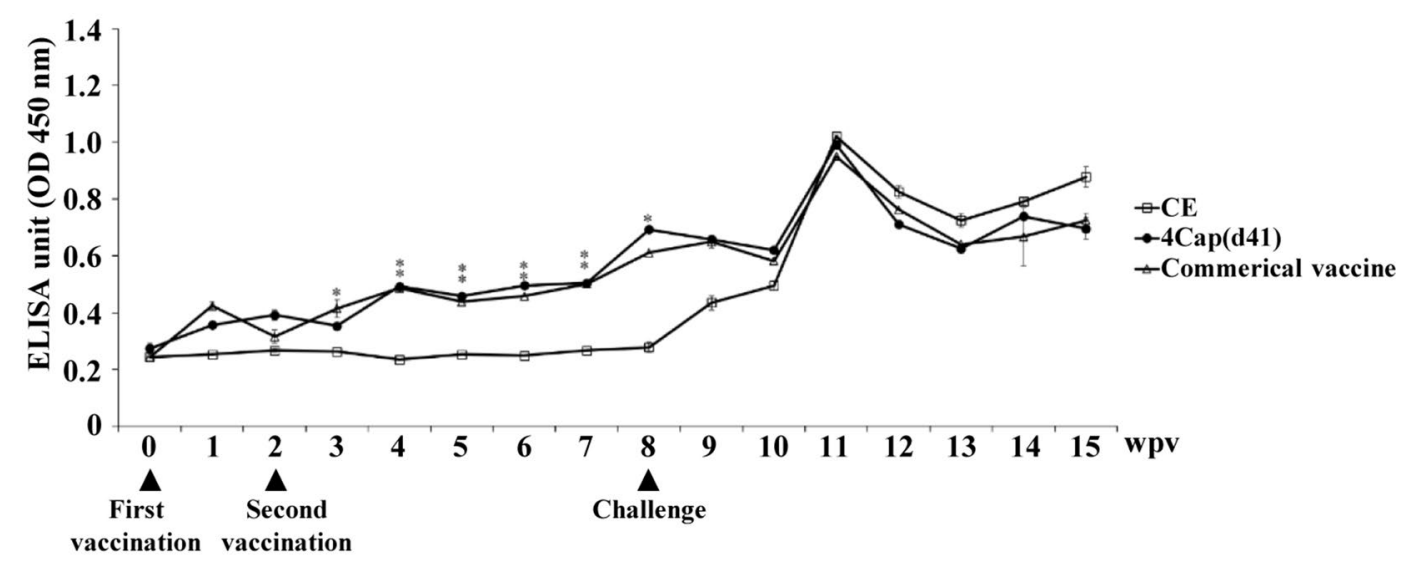

Figure 8 Detection of anti-PCV2 titers by ELISA. 2-month-old SPF pigs were immunized at the base of the ear by the intramuscular route with $C E, 4 C a p(d 41)$, and commercial vaccines, respectively. Serum samples were collected every week after the first immunization to determine the Cap-specific ELISA antibodies. In the eighth week after the first immunization, all vaccinated pigs were intranasally injected with $2 \mathrm{ml}$ of PCV2 $\left(10^{5.7} \mathrm{TCID}_{50} / \mathrm{mL}\right)$. Data represent the mean $\pm \mathrm{SD}$. An asterisk $\left(^{*}\right)$ shows a statistically significant difference between the indicated groups $(P<0.05)$.

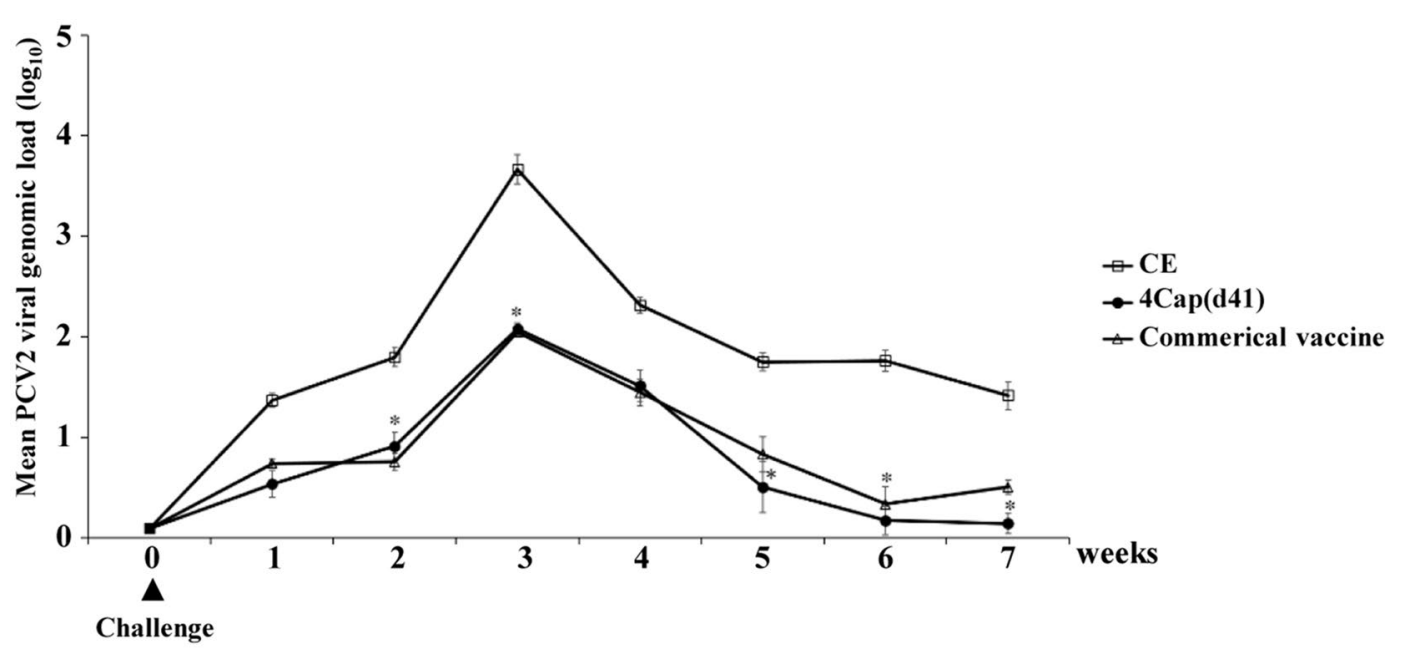

Figure 9 Quantification of PCV2 viral loads in sera from the challenged pigs. 2-month-old SPF pigs were immunized at the base of the ear by the intramuscular route with $\mathrm{CE}, 4 \mathrm{Cap}(\mathrm{d} 41)$, and commercial vaccines, respectively. Serum samples were collected every week after the first immunization. In the eighth week after the first immunization, all vaccinated pigs were challenged via intranasal injection with $2 \mathrm{ml}$ of PCV2 $\left(10^{5.7} \mathrm{TCID} 50 / \mathrm{mL}\right)$. The $8^{\text {th }}$ week after the first immunization is designated as the $0^{\text {th }}$ week. PCV2 viral loads were detected by real-time quantitative PCR one week post challenge. Data are presented as mean \pm SD. Viral loads were determined as the mean of the logarithmic DNA copy number per $\mathrm{ml}(\log$ copies/ml). An asterisk (*) shows a statistically significant difference between the indicated groups $(\mathrm{P}<0.05)$.

expression systems are the obstacles when the products are developed for commercial application. In the present study, we have successfully constructed three novel baculovirus surface display vectors with multiple expression cassettes for high level expression of the PCV Cap(d41) protein. In this work, coexpression of EGFP allowed rapid identification of the recombinant baculovirus in Sf-9 insect cells, eliminating cumbersome and time-consuming assays [42]. As the number of expression cassettes in the recombinant baculovirus increases, the expression levels of $\mathrm{Cap}(\mathrm{d} 41)$ protein also increased. The higher expression levels of the Cap(d41) protein with the recombinant baculovirus BacDD-4Cap(d41) is about twice that of BacSC-Cap $(\mathrm{d} 41)$. It is curious that the expression levels of the PCV2 Cap (d41) protein may not necessarily be the same as the number of expression cassettes of the vector increase. We found that the expression level of the PCV2 Cap $(\mathrm{d} 41)$ protein by recombinant virus BacDD-3Cap(d41) is close to the expression level of $\mathrm{Cap}(\mathrm{d} 41)$ protein by recombinant virus BacDD-4Cap 
$\backslash(\mathrm{d} 41)$. It is speculated that the reason may be that multiple expression cassettes are constructed using the p10 or polh promoters, which control expression of the p10 and polyhedrin proteins, which are expressed concurrently during the late stage of infection. This could result in competition between promoters leading to decreased expression efficiency. This hypothesis is further supported by an earlier study suggesting that expression from the p10 promoter inhibits the transcriptional activity of the polh promoter [43].

This study also tested the optimal conditions for expressing the Cap $(\mathrm{d} 41)$ protein with the recombinant baculoviruses BacSC-Cap(d41), BacDD-2Cap(d41), BacDD-3Cap(d41) and BacDD-4Cap(d41). Our results reveal that these viruses yield low levels of protein expression on the second day after infection of the cells, and the highest levels on the fourth day after infection. Although Cap $(\mathrm{d} 41)$ protein expression is the highest on the fourth day after virus infection, serious cytopathic effect (CPE) was observed, which may affect the quality of Cap(d41). The cells after infection must maintain their integrity to ensure the quality of the expressed protein. One previous study found that expression of exogenous proteins in insect cells causes the degradation of exogenous proteins. The rate of protein synthesis is the same as the rate of degradation 1 day after infection. The degradation does not disappear until 3-4 days after infection in insect cells [44]. This may explain why after 2 days of infection with insect cells, the PCV2 $4 \mathrm{Cap}(\mathrm{d} 41)$ protein was still not detected (Figure 4A). Due to serious cytopathic effect (CPE) and the increase in production costs on the fourth day after virus infection, we conclude that 3 days of infection is more suitable for protein production. Among the MOI tested, both 5 and 10 MOIs have higher levels of protein expression. Furthermore, we also found that $10^{7}$ of Sf- 9 cells infected with the recombinant baculovirus BacDD-4Cap (d41) produced higher expression levels of Cap $(\mathrm{d} 41)$ protein and elicited higher levels of ELISA titers than that of cell number $10^{5}$ and $10^{6}$ of Sf-9 cells. Thus, this study suggests that incubating virusinfected cells for 3 days, 5-10 MOI, and cell number of $10^{7} \mathrm{Sf}-9$ cells are the optimal conditions for mass production of the Cap $(\mathrm{d} 41)$ protein.

An effective vaccine must induce both humoral and cellular immune responses to prevent diseases. In the present study, a virus neutralization test confirmed that pigs immunized with the $4 \mathrm{Cap}(\mathrm{d} 41)$ vaccine can induce a neutralizing antibody titer of 1:22. We found that the $4 \mathrm{Cap}(\mathrm{d} 41)$ vaccine significantly reduces the viral load of vaccinated pigs (Figure 9). These data are consistent with a previous report suggesting that a neutralizing antibody titer of 1:11 can effectively inhibit viremia [40]. Although the PCV change induced similar levels of antibodies in
CE, 4Cap and commercial vaccines, our results showed that the $4 \mathrm{Cap}(\mathrm{d} 41)$ and the commercial vaccine groups significantly reduce the viral load of vaccinated pigs as compared with the CE negative control group. This could be $4 \mathrm{Cap}(\mathrm{d} 41)$ and commercial vaccines-induced higher levels of neutralizing antibody in mice and SPF pigs than that of the CE negative control group (Figures 5, 6).

Previous studies have shown that IFN- $\gamma$ is regarded as an important factor in the vaccine-induced cellular immune response [30]. Therefore, IFN- $\gamma$ was used as an indicator of cellular immunity in this study. $\mathrm{CD}^{+} \mathrm{T}$ lymphocytes can differentiate into Th1 and Th2. Th1 secretes IFN- $\gamma$ to activate $\mathrm{CD}^{+} \mathrm{T}$ lymphocytes and macrophages to kill foreign pathogens or infected cells. It was confirmed by IFN- $\gamma$ ELISA that both $4 \mathrm{Cap}(\mathrm{d} 41)$ and commercially available vaccines can stimulate immune cells to secrete IFN- $\gamma$ and induce cellular immune responses. This study reveals that the recombinant $4 \mathrm{Cap}(\mathrm{d} 41)$ group and the commercially available vaccine group can increase the number of $\mathrm{CD}^{+}{ }^{+} \mathrm{T}$ cells and the ratio of $\mathrm{CD}^{+} / \mathrm{CD}^{+}$and induce a significant higher levels of cellular immune response.

Our data reveal that both $4 \mathrm{Cap}(\mathrm{d} 41)$ and commercially available vaccines can induce the Th1 immune response as evidenced by higher levels of IFN- $\gamma$ production. This study shows that cell lysates from the recombinant baculovirus BacDD-4Cap(d41)-infected cells can trigger better humoral and cellular immune responses than that of BacSC-Cap(d41). This study confirmed that the Cap $(\mathrm{d} 41)$ protein with 41 amino acids deleted at the $\mathrm{N}$-terminus can be stably expressed in SF-9 cells. We successfully constructed a recombinant baculovirus BacDD4Cap(d41) carrying 4 expression cassettes to enhance protein expression. The optimal conditions for mass production of the Cap $(\mathrm{d} 41)$ protein are established, including incubating virus-infected cells for 3 days, 5-10 MOI, and cell number of $10^{7} \mathrm{Sf}-9$ cells for virus replication. In animal experiments, the $4 \mathrm{Cap}(\mathrm{d} 41)$ vaccine prepared from BacDD-4Cap(d41)-infected cells can trigger better humoral and cellular immune responses.

\section{Acknowledgements \\ Not applicable.}

\section{Authors' contributions}

$\mathrm{H}-\mathrm{LL}$ conceived and designed the experiments. YY-C, W-CY, W-RH, and J-YL performed the experiments. Y-KC, C-YW, K-P Chuang, H-YW, C-DC, and H-JL analyzed the data. $\mathrm{H}-J \mathrm{~L}$ and BLN wrote and revised the manuscript. All authors read and approved the final manuscript.

\section{Funding}

This work was supported by the grants from Council of Agriculture of Taiwan (100AS-1.1.5-BQ-H3-6), Tung's Taichung MetroHarbor Hospital (TTMHH109 R0026), the iEGG and Animal Biotechnology Center from The Feature Areas Research Center Program within the framework of the Higher Education Sprout Project by the Ministry of Education (MOE) in Taiwan (109S0023A), and 
Ministry of Science and Technology of Taiwan (MOST108-2622-B-005-001-CC2, MOST 109-2313-B-005-006-MY3).

\section{Availability of data and materials}

The datasets supporting the conclusions of this article are included within the article.

\section{Ethics approval and consent to participate}

The animal experiment protocol used in this work was approved by the Research Ethics Committee of National Chung Hsing University (IACUC No. 104-073). All swine and mouse experimental procedures were carried out according to the Regulations for the Administration of Affairs Concerning Experimental Animals approved by Council of Agriculture, Taiwan.

\section{Consent to publish}

Not applicable.

\section{Competing interests}

The authors declare that they have no competing interests.

\section{Author details}

1 Department of Stomatology, Tung's Taichung MetroHarbor Hospital, Taichung, Taiwan. ${ }^{2}$ Medical Biotechnology, National Chung Hsing University, Taichung 402, Taiwan. ${ }^{3}$ Institute of Molecular Biology, National Chung Hsing University, Taichung 402, Taiwan. ${ }^{4}$ Department of Medical Research, Tung's Taichung MetroHarbor Hospital, Taichung, Taiwan. ${ }^{5}$ Department of Nursing, JenTeh Junior College of Medicine and Management, Hou-Long, Taiwan. ${ }^{6}$ Department of Veterinary Medicine, National Chung Hsing University, Taichung 402, Taiwan. ${ }^{7}$ Graduate Institute of Animal Vaccine Technology, National Pingtung University of Science and Technology, Pingtung 912, Taiwan. ${ }^{8}$ Department of Veterinary Medicine, National Pingtung University of Science and Technology, Pingtung 912, Taiwan. ${ }^{9}$ Department of Microbiology and Molecular Biology, Brigham Young University, Provo, UT, USA. ${ }^{10}$ The iEGG and Animal Biotechnology Center, National Chung Hsing University, Taichung 402, Taiwan. ${ }^{11}$ Rong Hsing Research Center for Translational Medicine, National Chung Hsing University, Taichung 402, Taiwan. ${ }^{12}$ Translational Medicine, National Chung Hsing University, Taichung 402, Taiwan. ${ }^{13}$ Department of Life Sciences, National Chung Hsing University, Taichung, Taiwan.

Received: 24 June 2020 Accepted: 27 August 2020 Published online: 09 September 2020

\section{References}

1. Tischer I, Gelderblom H, Vettermann W, Koch MA (1982) A very small porcine virus with circular single-stranded DNA. Nature 295:64-66

2. Zhang HH, Hu WQ, Li JY, Liu TN, Zhou JY, Opriessnig T, Xiao CT (2020) Novel circovirus species identified in farmed pigs designated as porcine circovirus 4, Hunan province, China. Transbound Emerg Dis 67(3):1057-1061

3. Chae C (2004) Postweaning multisystemic wasting syndrome: a review of aetiology, diagnosis and pathology. Vet J 168:41-49

4. Hamel AL, Lin LL, Nayar GP (1998) Nucleotide sequence of porcine circovirus associated with postweaning multisystemic wasting syndrome in pigs. J Virol 72:5262-5267

5. Mahe D, Blanchard P, Truong C, Arnauld C, Le Cann P, Cariolet R, Madec F, Albina E, Jestin A (2000) Differential recognition of ORF2 protein from type 1 and type 2 procine circoviruses and identification of immunorelevant epitopes. J Gen Virol 81:1815-1824

6. Pogranichnyy RM, Yoon KJ, Harms PA, Swenson SL, Zimmerman JJ, Sorden SD (2000) Characterization of immune response of young pigs to porcine circovirus type 2 infection. Viral Immunol 13:143-153

7. Nawagitgul P, Morozov I, Bolin SR, Harms PA, Sorden SD, Paul PS (2000) Open reading frame 2 of porcine circovirus type 2 encodes a major capsid protein. J Gen Virol 81:2281-2287

8. Allan GM, McNeilly F, Ellis J, Krakowka S, Meehan B, McNair I, Walker I, Kennedy S (2000) Experimental infection of colostrums deprived piglets with porcine circovirus 2 (PCV2) and porcine reproductive and respiratory syndrome virus. Arch Virol 145:2421-2429
9. Segales J, Allan GM, Domingo M (2005) Porcine circovirus diseases. Anim Health Res Rev 6(2):119-142

10. Nayar GP, Hamel A, Lin L (1997) Detection and characterization of porcine circovirus associated with postweaning multisystemic wasting syndrome in pigs. Can Vet J 38:385-386

11. Kim J, Chung HK, Jung T, Cho WS, Choi C, Chae C (2002) Postweaning multisystemic wasting syndrome of pigs in Korea: prevalence, microscopic lesions and coexisting microorganisms. J Vet Med Sci 64:57-62

12. Clark EG (1997) Post-weaning multisystemic wasting syndrome. In: Proceedings of the American Association of Swine Practitioners, 28th annual meeting. pp 499-501

13. Harding JC (1996) Post-weaning multi-systemic wasting syndrome (PMWS): preliminary epidemiology and clinical presentation. In: Proceedings of the Western Canadian Association Swine Practioners Annual Meeting. p 21

14. Segales J, Sitjar JM, Domingo M, Dee S, Del Pozo M, Noval R, Sacristan C, De las Heras A, Ferro A, Latimer KS (1997) First report of postweaning multisystemic wasting syndrome in Spain. Vet Rec 141:600-601

15. Allan GM, McNeilly F, Kennedy S, Daft B, Clarke EG, Ellis JA, Haines DM, Meehan BM, Adair BM (1998) Isolation of porcine 60 circovirus-like viruses from pigs with a wasting disease in the USA and Europe. J Vet Diagn Invest 10:3-10

16. Kennedy S, Allan G, McNeilly F, Adair BM, Hughes A, Spillane P (1998) Porcine circovirus infection in Northern Ireland. Vet Rec 142:495-496

17. Allan GM, McNeilly F, Meehan BM, Kennedy S, Mackie DP, Ellis JA, Clark EG, Espuna E, Saubi N, Riera P, Botner A, Charreyre CE (1999) Isolation and characterisation of circoviruses from pigs with wasting syndromes in Spain, Denmark and Northern Ireland. Vet Microbiol 66:115-123

18. Tsai SS, Chang CT, Chang CD, Chien MS, Chen SP, Weng CH, Itakura C (1997) A retrospective study of circovirus infection in pigs. Taiwan J Vet Med Anim Husbandry 67:27

19. Lu HY, Chen YH, Liu HJ (2012) Baculovirus as vaccine vector. Bioengineered 3(5):1-4

20. Tung MC, Lu HY, Chang UK, Huang WR, Liao TL, Wu HY, Chang CD, Fan HC, Nielsen BL, Liu HJ (2020) Baculovirus surface display of the HA protein of H5N2 avian influenza virus and its immunogenicity against a lethal challenge with $\mathrm{H} 5 \mathrm{~N} 1$ virus in chickens. Vet Microbiol 243:108640

21. Lin YH, Lee LH, Shih WL, Hu YC, Liu HJ (2008) Baculovirus surface display of sigma $C$ and sigma B proteins of avian reovirus and immunogenicity of the displayed proteins in a mouse model. Vaccine 26:6361-6367

22. Yang DG, Chung YC, Lai YK, Lai CW, Liu HJ, Hu YC (2007) Avian influenza virus hemagglutinin display on baculovirus envelope: cytoplasmic domain affects virus properties and vaccine potential. Mol Ther 15:989-996

23. Fan $H$, Xiao S, Tiezhu T, Wang S, Xie L, Jiang Y, Chenb H, Fang L (2008) Immunogenicity of porcine circovirus type 2 capsid protein targeting to different subcellular compartments. Mol Immunol 45:653-660

24. Yang ZY, Wangd CY, Lee LW, Chuang KP, Lien YP, Yin HS, Tong DW, Xu XG, Liu HJ (2010) Development of ELISA kits for antibodies against avian reovirus using the $\sigma \mathrm{C}$ and $\sigma \mathrm{B}$ proteins expressed in the methyltropic yeast Pichia pastoris. J Virol Methods 163:169-174

25. Huang WR, Chi PI, Chiu HC, Hsu JL, Nielsen BL, Liao TL, Liu HJ (2017) Avian reovirus p17 and $\sigma \mathrm{A}$ act cooperatively to downregulate Akt by suppressing mTORC2 and CDK2/cyclin A2 and upregulating proteasome subunit PSMB6. Sci Rep 7:5226-5244

26. Chiu HC, Huang WR, Liu JH, Chi PI, Nielsen BL, Liao TL, Liu HJ (2018) Mechanistic insights into avian reovirus p17-modulated suppression of cell-cycle CDK/cyclin complexes and enhancement of p53 and cyclin $\mathrm{H}$ interaction. J Biol Chem 293(32):12542-12562

27. Reed $\sqcup$, Muench $H$ (1938) A simple method of estimating fifty percent endpoints. Am J Hygiene 27:493-497

28. Ke GM, Cheng HL, Ke LY, Ji WT, Chulu JL, Chang TJ, Liu HJ (2006) Development of a quantitative light cycler real-time RT-PCR for detection of avian reovirus. JVirol Methods 133:6-13

29. Pan QX, He KW, Huang KH (2008) Development of recombinant porcine parvovirus-like particles as an antigen carrier formed by the hybrid VP2 protein carrying immunoreactive epitope of porcine circovirus type 2. Vaccine 26:2119-2126

30. Fort M, Fernandes LT, Nofrarias M, Diaz I, Sibila M, Pujols J, Mateu E, Segales JJ (2009) Development of cell-mediated immunity to porcine 
circovirus type 2 (PCV2) in caesarean-derived, colostrum-deprived piglets. Vet Immunol Immunopathol 129:101-107

31. Fenaux M, Opriessnig T, Halbur PG, Elvinger F, Meng X (2004) A chimeric porcine circovirus (PCV) with the immunogenic capsid gene of the pathogenic PCV type 2 (PCV2) cloned into the genomic backbone of the nonpathogenic PCV1 induces protective immunity against PCV2 infection in pigs. JVirol 78:6297-7303

32. Kamstrup S, Barfoed AM, Frimann TH, Ladekjaer-Mikkelsen AS, Bøtner A (2004) Immunisation against PCV2 structural protein by DNA vaccination of mice. Vaccine 22(11-12):1358-1361

33. Pogranichniy R, Yoonl KJ, Yaeger M, (2004) Possible prevention of PMWS using inactivated PCV2 vaccine in CDCD pigs. In: Proceedings of the 18th IPVS Congress. vol. 1. p 55

34. Ju C, Fan H, Tan Y, Liu Z, Xi X, Cao S, Wu B, Chen H (2005) Immunogenicity of a recombinant pseudorabies virus expressing ORF1-ORF2 fusion protein of porcine circovirus type 2. Vet Microbiol 109(3-4):179-190

35. Tu Y, Wang Y, Wang G, Wu J, Liu Y, Wang S, Jiang C, Cai X (2013) High-level expression and immunogenicity of a porcine circovirus type 2 capsid protein through codon optimization in Pichia pastoris. Appl Microbiol Biotechnol 97(7):2867-2875

36. XU XG, Liu HJ (2008) Baculovirus surface display of E2 envelope glycoprotein of classical swine fever virus and immunogenicity of the displayed proteins in a mouse model. Vaccine 26:5455-5460

37. Li D, Du Q, Wu B, Li J, Chang L, Zhao X, Huang Y, Tong D (2017) Immunogenicity of adenovirus vaccines expressing the PCV2 capsid protein in pigs. Vaccine 35:4722-4729

38. Lekcharoensuk P, Morozov I, Paul PS, Thangthumniyom N, Wajjawalku W, Meng XJ (2004) Epitope mapping of the major capsid protein of type
2 porcine circovirus (PCV2) by using chimeric PCV1 and PCV2. J Virol 78:8135-8145

39. Liu Q, Tikoo SK, Babiuk LA (2001) Nuclear localization of the ORF2 protein encoded by porcine circovirus type 2. Virology 285:91-99

40. Xu XG, Wang ZS, Zhang Q, Li ZC, Ding L, Li W, Wu HY, Chang CD, Lee LH, Tong DW, Liu HJ (2012) Baculovirus as a PRRSV and PCV2 bivalent vaccine vector: baculovirus virions displaying simultaneously GP5 glycoprotein of PRRSV and capsid protein of PCV2. J Virol Methods 179:359-366

41. Xu XG, Wang ZS, Zhang Q, Li ZC, Zhao ZN, Li W, Tong DW, Liu HJ (2011) Baculovirus surface display of E envelope glycoprotein of Japanese encephalitis virus and its immunogenicity of the displayed proteins in mouse and swine models. Vaccine 29:636-643

42. Hu YC, Luo YL, Ji WT, Chulu JL, Chang PC, Shieh HY, Wang CY, Liu HJ (2006) Dual expression of the HA protein of H5N2 avian influenza virus in a Baculovirus system. J Virol Methods 135:43-48

43. Chaabihi H, Ogliastro MH, Martin M, Giraud C, Devauchelle G, Cerutti M (1993) Competition between baculovirus polyhedrin and p10 gene expression during infection of insect cells. J Virol 67:2664-2671

44. Licari P, Bailey JE (1991) Factors influencing recombinant protein yields in an insect cell-bacuiovirus expression system: multiplicity of infection and intracellular protein degradation. Biotechnol Bioeng 37:238-246

\section{Publisher's Note}

Springer Nature remains neutral with regard to jurisdictional claims in published maps and institutional affiliations.
Ready to submit your research? Choose BMC and benefit from:

- fast, convenient online submission

- thorough peer review by experienced researchers in your field

- rapid publication on acceptance

- support for research data, including large and complex data types

- gold Open Access which fosters wider collaboration and increased citations

- maximum visibility for your research: over 100M website views per year

At BMC, research is always in progress.

Learn more biomedcentral.com/submissions 